Article

\title{
An Integrated Hydraulic and Hydrologic Modeling Approach for Roadside Bio-Retention Facilities
}

\author{
James Li *, Seyed Alinaghian, Darko Joksimovic $®$ and Lianghao Chen \\ Department of Civil Engineering, Ryerson University, Toronto, ON M5B 2K3, Canada; \\ Alex.Alinaghian@ryerson.ca (S.A.); darkoj@ryerson.ca (D.J.); lianghao.chen@peelregion.ca (L.C.) \\ * Correspondence: jyli@ryerson.ca; Tel.: +001-416-979-5345
}

Received: 20 March 2020; Accepted: 18 April 2020; Published: 27 April 2020

check for updates

\begin{abstract}
Roadside bio-retention (RBR) facilities are low impact development practices, which control urban runoff primarily from road pavements. Using hydrologic models, such as the US EPA Storm Water Management Model (SWMM), RBR are typically designed with some fundamental assumptions, including where runoff completely enters the facilities and fully utilizes the whole surface area for percolation, detention, filtration, and infiltration to the surrounding soils. This paper highlights the importance of inlet hydraulics and the spatial distribution of inflow along a RBR, and proposes an integrated hydraulic and hydrologic modelling approach to simulate its overall runoff control performance. The integrated hydraulic/hydrologic modelling approach consists of three components: (1) A dual drainage hydrologic model to simulate runoff generation, runoff hydrographs entering and bypassing a storm inlet, and the outflow hydrograph from a fully utilized RBR; (2) a computational fluid dynamic model to determine the inflow distribution along a RBR; and (3) an overall runoff control performance analysis of RBR by considering the inlet efficiency, and the partially and fully utilized RBR during a storm event. A case study of an underground RBR in the City of Toronto was used to demonstrate the integrated modelling approach. It is concluded that; (1) inlet efficiency of a RBR will determine the overall runoff control performance; and (2) the inflow distribution will dictate the effective length of a RBR, which may affect the overall runoff control performance.
\end{abstract}

Keywords: bio-retention; green infrastructure; runoff control performance; storm inlet hydraulics; flow distribution hydraulics

\section{Introduction}

In order to control runoff problems (e.g., increased flooding, deterioration of water quality, receiving channel erosion) associated with urban development, low impact development (LID) aims at restoration of pre-development hydrology by utilizing spatially distributed LID practices throughout a drainage catchment [1]. LID practices have been recognized to harness natural hydrologic processes, in order to "manage rainfall at the source, using uniformly distributed decentralized micro-scale control"; [2] and can be divided into lot-based, road right-of-way-based, and area-based types [1]. Lot-based LID practices are facilities on a single parcel of land, such as a building lot. Right-of-way (ROW)-based LID practices are facilities within the area of land that is acquired for or devoted to the provision of a road [3]. Area-based LID practices, also known as multi-lot LIDs, are located on large pieces of land such as parks. Among all these different types of LIDs, ROW-based LIDs are the most difficult facilities to implement, due to lack of space and the layout of the road drainage and surrounding utility system. Nevertheless, storm runoff along ROW should be controlled because the total road drainage area of some highly urbanized cities or regions can be as large as adjacent building lots and open space. Several innovative structural techniques to control ROW runoff include bio-retentions, porous pavement, catch basin filters, sewer trench exfiltration systems, perforated 
sewers, and exfiltration tanks [1,4-6]. Among all these techniques, ROW-based LIDs, such as roadside bio-retentions (RBR) are becoming popular and can be integrated into roadside landscaping green space. RBR has two common types:

(1) Conventional surface RBR with a surface plant soil layer

Storm runoff, generates from a section of the ROW, is captured by one or multiple inlets (e.g., curb cuts or openings) to a RBR, either on a sidewalk or the median of the road. It can be integrated into the neighborhood green space or flower beds. A typical RBR consists of the top vegetation layer, intermediate filter media (e.g., sandy loam), intermediate transition layer (e.g., coarse sand), a drainage layer (e.g., coarse sand and gravel) with, and without, a perforated underdrain collection pipe [7]. Runoff entering the RBR can temporarily pond at the surface layer and subsequently infiltrate into the various layers of the bio-retention cell. There may be an overflow pipe at the surface layer for excess runoff conveyance. The percolated runoff can go, either to the surrounding native soil, or an underdrain pipe connecting back to the road storm sewer [8].

(2) Underground RBR without a surface layer (Figure 1)

The layout of this RBR is similar to the conventional one except the absence of the top soil-plant layer. This type of RBR is commonly used in highly urbanized area. The inlets can be in the form of a grate and/or curb opening catch basin, which conveys the captured runoff to the bio-retention cell through an upper perforated flow distribution pipe. The percolated runoff can go either to the surrounding native soil and/or an underdrain pipe connecting back to the road storm sewer. It is useful for highly urbanized areas, since it can be constructed under the sidewalk and part of the road without affecting parking space [9].

Current research studies on RBR, as summarized below, have focused primarily on runoff volume-controlled, water pollutant removal, enhanced soil mix, and clogging using laboratory, and field scale investigations and mathematical modeling.

(1) Laboratory scale research

Laboratory studies of RBR using bio-retention boxes and columns have focused on hydrologic performance [10,11], water quality treatment [12], heavy metal removal efficiency [13,14], organic carbon removal efficiency [15,16], nutrient removal efficiency [17,18], effect of salts on performance $[13,19,20]$, and root effect on infiltration rates [11].

(2) Field scale research

Field studies of RBR have been conducted to investigate the effect of plant and fungal contributions to performance [21], soil phosphorus release [22], treatment efficiency of runoff highway bridge deck [23], heavy metal removal efficiency [24-26], nitrogen removal efficiency [27,28], greenhouse gas release [29,30], hydraulic properties and infiltration rates [31] and operation and maintenance $[32,33]$.

(3) Mathematical modeling research

Mathematical modeling studies of RBR have focused on sizing and optimization methods [25,34-36]; hydrologic performance [37-39], and hydraulic and hydrologic performance [40-44].

Research of storm inlet hydraulics has dated back to 1950s [45-47], continued through 1990s [48], and in the last 10 years [49-54]. However, the effect of inlet hydraulics on the overall performance of RBR has only been investigated recently $[55,56]$. This paper focuses on this research gap and further investigates the captured inflow distribution, along an underground RBR using laboratory experiments, 
computational fluid dynamic (CFD) simulations, and hydrological modelling. A case study of an underground RBR in Toronto (Figures 1 and 2) is used as a demonstration of the integrated hydraulic and hydrologic approach to model the overall performance evaluation of the RBR. The case study RBR was designed as a treatment LID without infiltration and all percolated runoff was collected by an underdrain to the street storm sewer.

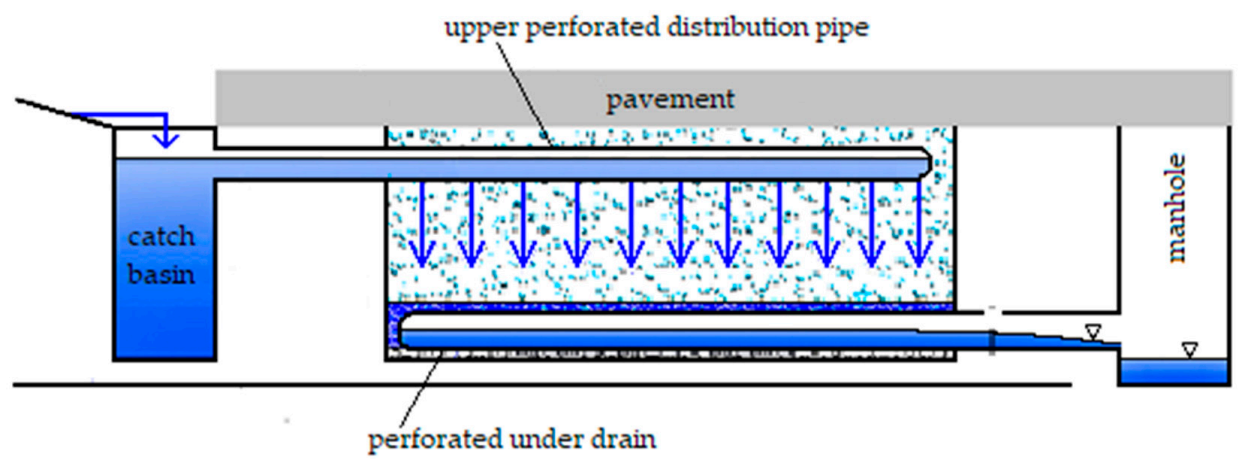

Figure 1. An underground RBR without a surface layer.
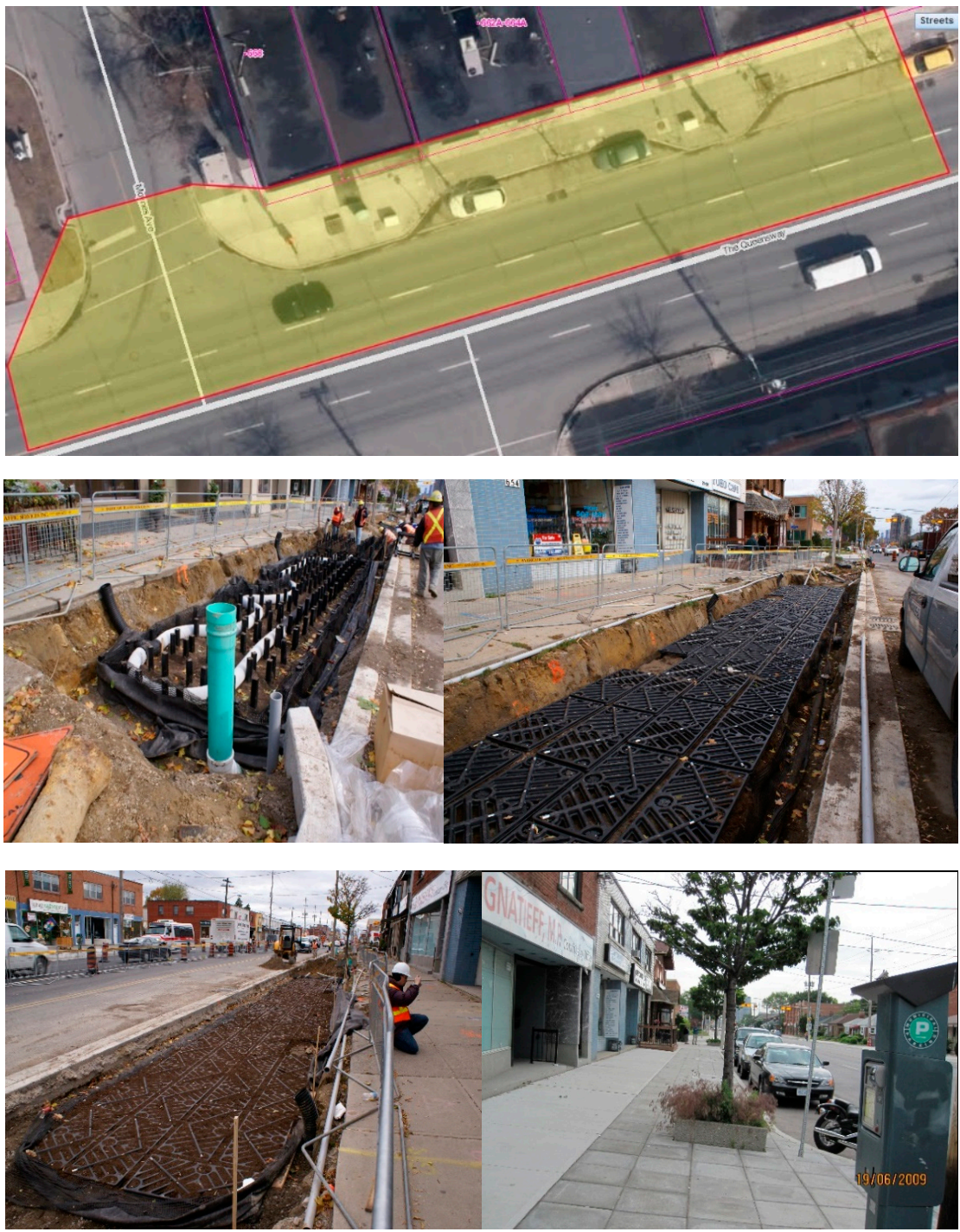

Figure 2. Construction phases of the Toronto underground RBR without a surface layer. 


\section{Materials and Methods}

The integrated hydraulic and hydrologic modelling approach for the overall performance analysis of an underground RBR is based on the tracking of runoff from a road drainage area, which enters a storm inlet and the RBR, and exits the RBR by, either infiltration to the surrounding soil, or conveyance through a bottom underdrain to the storm sewer. It consists of three consecutive components: (1) Development of a dual drainage hydrologic model, which simulates runoff hydrographs entering and bypassing a RBR and the runoff control performance of a fully utilized RBR; (2) hydraulic simulations of the inflow distribution along a RBR; and (3) determination of the overall runoff control performance of a RBR with outflow adjustments for partially utilization of the RBR during a storm event. A case study of an underground RBR without a surface layer implemented at the City of Toronto is used to illustrate the integrated modelling approach.

\subsection{A Dual Drainage Hydrologic Model for a Fully Utilized Underground RBR}

SWMM [57] is a popular hydrological analysis model for urban drainage planning and design. The PCSWMM software (Computational Hydraulics International, Guelph, ON, Canada) [58], utilizing the SWMM computational engine, can be used to develop a dual drainage hydrologic model for an underground RBR. PCSWMM simulates runoff along a street and to a storm sewer by specifying the section characteristic of a street (e.g., length, width, curb height, cross-slope, bank-slope and bank-height) and the sewer characteristics (e.g., length, roughness, inlet and outlet elevations, cross-section and geometry). Runoff enters a storm inlet longitudinally along the road gutter (i.e., frontal flow) and laterally from the side of a road (i.e., side flow). The captured runoff by a storm inlet becomes the inflow to a RBR. The total capacity of storm inlets is normally designed to match the storm sewer capacity (e.g., runoff rate associated with a storm of two or five year return period in Canada). For each type of inlets, there is an inlet capacity curve (e.g., Figure 3), which defines the total intercepting flow (e.g., outflow in Figure 3 on the Y-axis) at different hydraulic heads above the inlet (e.g., X-axis in Figure 3). Using an inlet capacity curve, a dual drainage model can be developed to determine the captured and bypassed runoff hydrographs at a storm inlet. The PCSWMM also has a LID module which can be used to model the infiltration and the underdrain flow of a RBR. As a result, PCWMM has the flow simulation mechanisms to track runoff generated from a road drainage area, the bypassed and captured runoff at a storm inlet, and the inflow and outflow of an underground RBR.

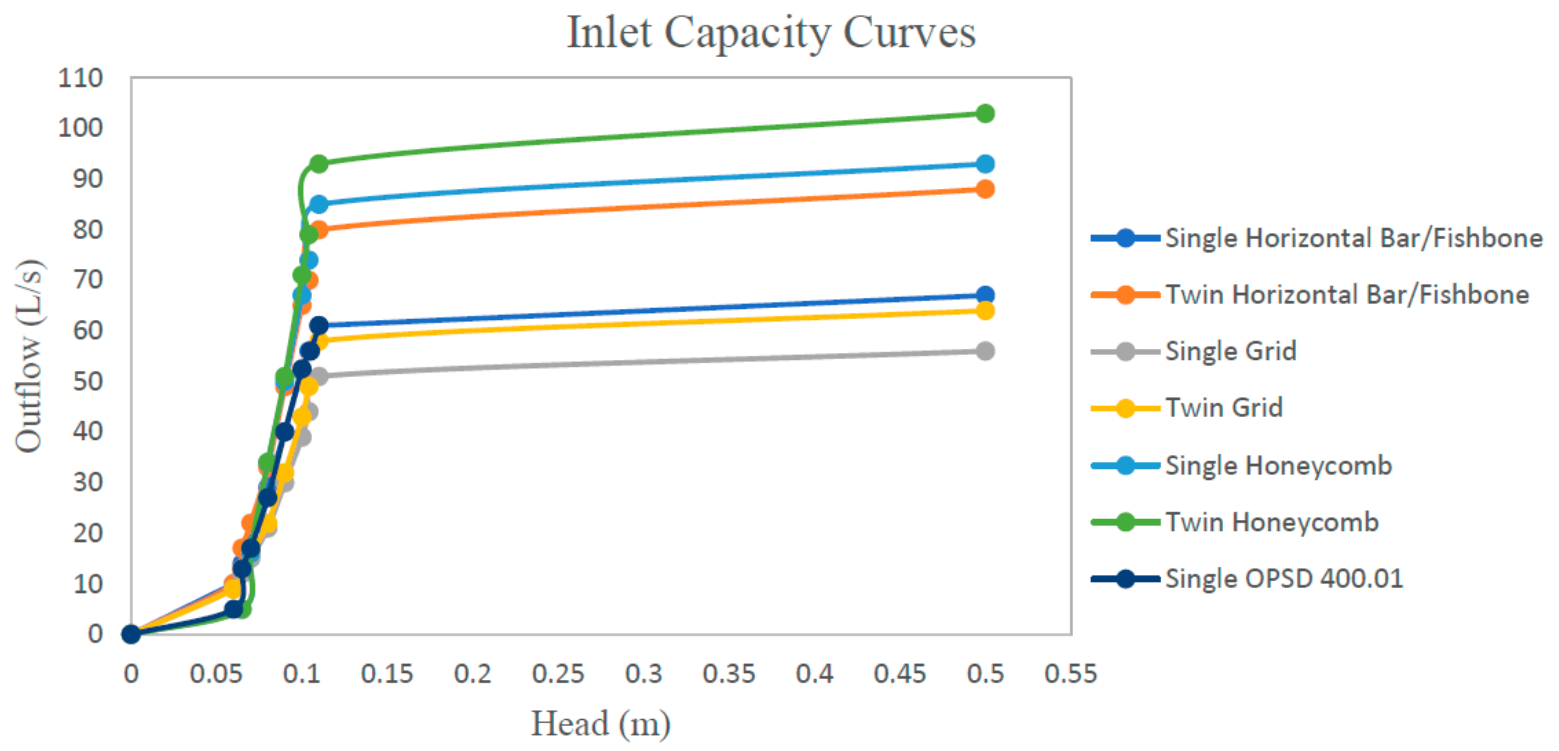

Figure 3. Toronto inlet capacity curves for different catch basins. 
As an example, the dual drainage model of the Toronto RBR is shown in Figure 4 and Tables 1-3. Chicago design storms (Figure 5) with different return periods (2-, 5-, 10-, 25-, and 100-year) were used as rainfall inputs to the PCSWMM dual drainage model, which simulated the runoff hydrograph from the drainage area, the storm inlet bypass hydrograph, the inflow and outflow hydrographs of the RBR for different design storm conditions. All these simulated hydrographs were used to determine the overall runoff control performance of the RBR.

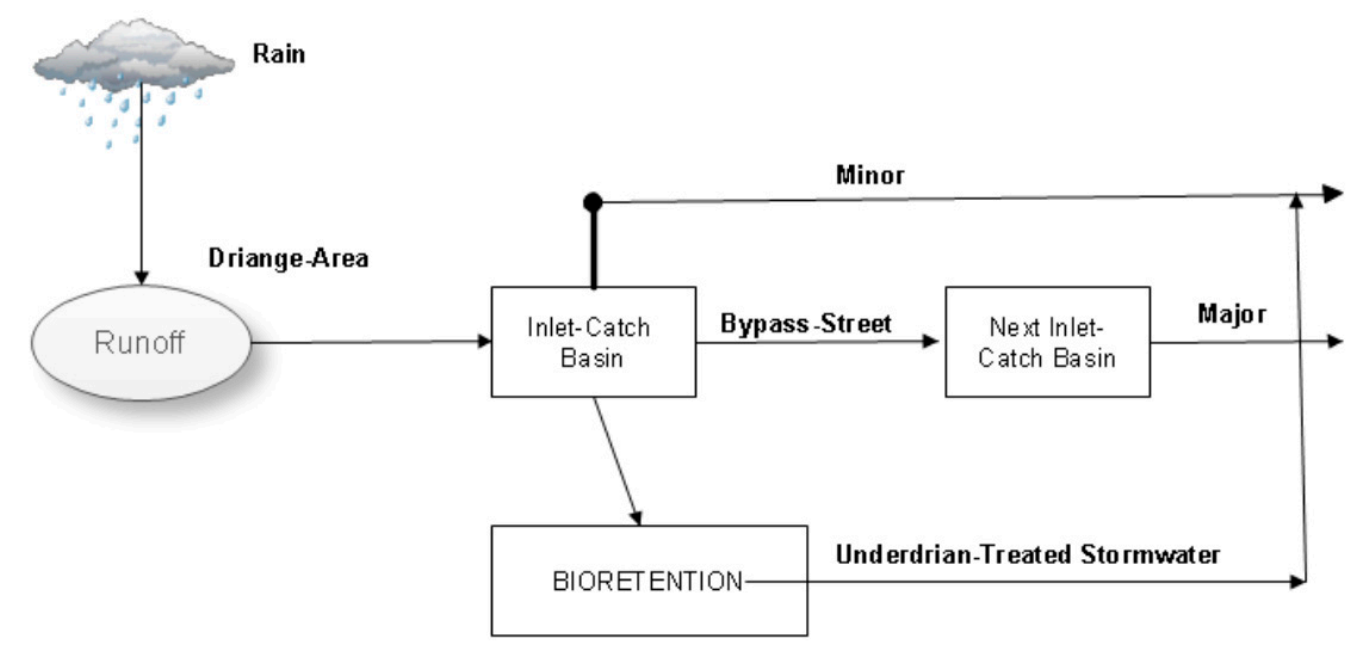

(a)
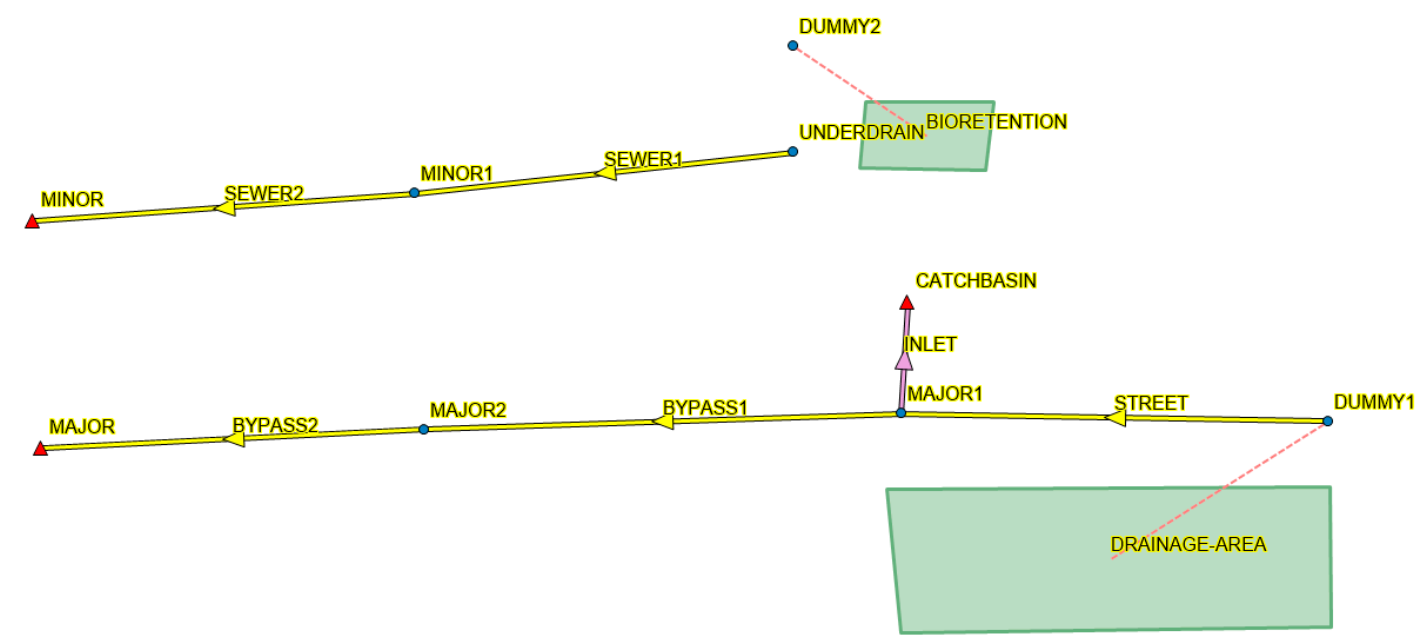

(b)

Figure 4. (a) Flow pathways through the RBR; (b) The dual drainage model of the Toronto RBR. 
Table 1. Input parameters for the drainage area.

\begin{tabular}{ccc}
\hline Inputs & Drainage-Area & Bioretention \\
\hline Area (ha) & 0.1074 & 0.0059 \\
Flow Length (m) & 74.554 & 18.081 \\
Width (m) & 14.352 & 3.2 \\
Slope (\%) & 0.8 & 0.5 \\
Imperv. (\%) & 100 & 0 \\
N Imperv & 0.011 & 0.011 \\
N Perv & 0.1 & 0.24 \\
Dstore Imperv (mm) & 1.25 & 0.127 \\
Dstore Perv (mm) & 2.5 & 0.508 \\
Zero Imperv (\%) & 100 & 0 \\
\hline
\end{tabular}

Table 2. Input parameters for the street and the sewer.

\begin{tabular}{ccc}
\hline Inputs & Street & Sewer1 \\
\hline Length $(\mathrm{m})$ & 74.552 & 70 \\
Roughness & 0.016 & 0.011 \\
Inlet Elevation $(\mathrm{m})$ & 91.03 & 90.43 \\
Outlet Elevation $(\mathrm{m})$ & 90.43 & 89.87 \\
Cross-Section & Irregular & Circular \\
Geom 1 (m) & Transect: Street1 & 0.5 \\
\hline
\end{tabular}

Table 3. Input parameters for the bioretention.

\begin{tabular}{|c|c|c|c|c|c|c|}
\hline \multicolumn{7}{|c|}{ Surface Layer } \\
\hline $\begin{array}{l}\text { Berm Height } \\
(\mathrm{mm})\end{array}$ & \multicolumn{2}{|c|}{ Vegetation Volume (fraction) } & \multicolumn{2}{|c|}{$\begin{array}{l}\text { Surface Roughness } \\
\text { (Manning's n) }\end{array}$} & \multicolumn{2}{|c|}{ Surface Slope (\%) } \\
\hline 0.001 & \multicolumn{2}{|c|}{0} & \multicolumn{2}{|c|}{0.1} & \multicolumn{2}{|c|}{0.001} \\
\hline \multicolumn{7}{|c|}{ Soil Layer } \\
\hline $\begin{array}{l}\text { Thickness } \\
(\mathrm{mm})\end{array}$ & $\begin{array}{l}\text { Porosity } \\
\text { (volume } \\
\text { fraction) }\end{array}$ & $\begin{array}{c}\text { Field Capacity } \\
\text { (volume } \\
\text { fraction) }\end{array}$ & $\begin{array}{l}\text { Witling Point } \\
\text { (volume } \\
\text { fraction) }\end{array}$ & $\begin{array}{l}\text { Conductivity } \\
(\mathrm{mm} / \mathrm{h})\end{array}$ & $\begin{array}{l}\text { Conductivity } \\
\text { Slope }\end{array}$ & $\begin{array}{c}\text { Suction } \\
\text { Head }(\mathrm{mm})\end{array}$ \\
\hline 600 & 0.437 & 0.105 & 0.047 & 29.97 & 10 & 60.96 \\
\hline \multicolumn{7}{|c|}{ Storage Layer } \\
\hline $\begin{array}{l}\text { Thickness } \\
(\mathrm{mm})\end{array}$ & \multicolumn{2}{|c|}{ Void Ratio (voids/solids) } & \multicolumn{2}{|c|}{ Seepage Rate $(\mathrm{mm} / \mathrm{h})$} & \multicolumn{2}{|c|}{ Clogging Factor } \\
\hline 600 & \multicolumn{2}{|c|}{0.5} & \multicolumn{2}{|c|}{0} & \multicolumn{2}{|c|}{0} \\
\hline \multicolumn{7}{|c|}{ Underdrain } \\
\hline $\begin{array}{c}\text { Drain } \\
\text { Coefficient } \\
(\mathrm{mm} / \mathrm{h})\end{array}$ & \multicolumn{2}{|c|}{ Drain Exponent } & \multicolumn{4}{|c|}{ Drain Offset Height (mm) } \\
\hline 339.17 & \multicolumn{2}{|c|}{0.5} & \multicolumn{4}{|c|}{0} \\
\hline
\end{tabular}




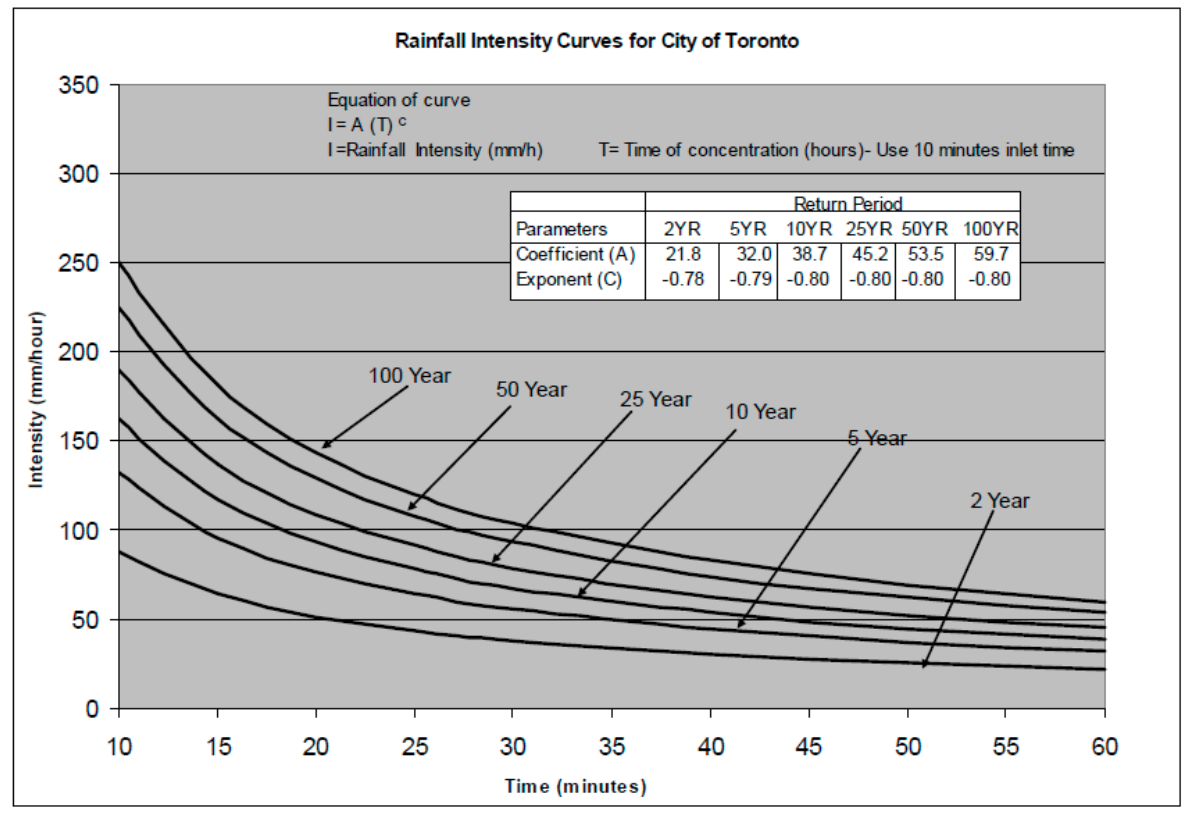

(a)

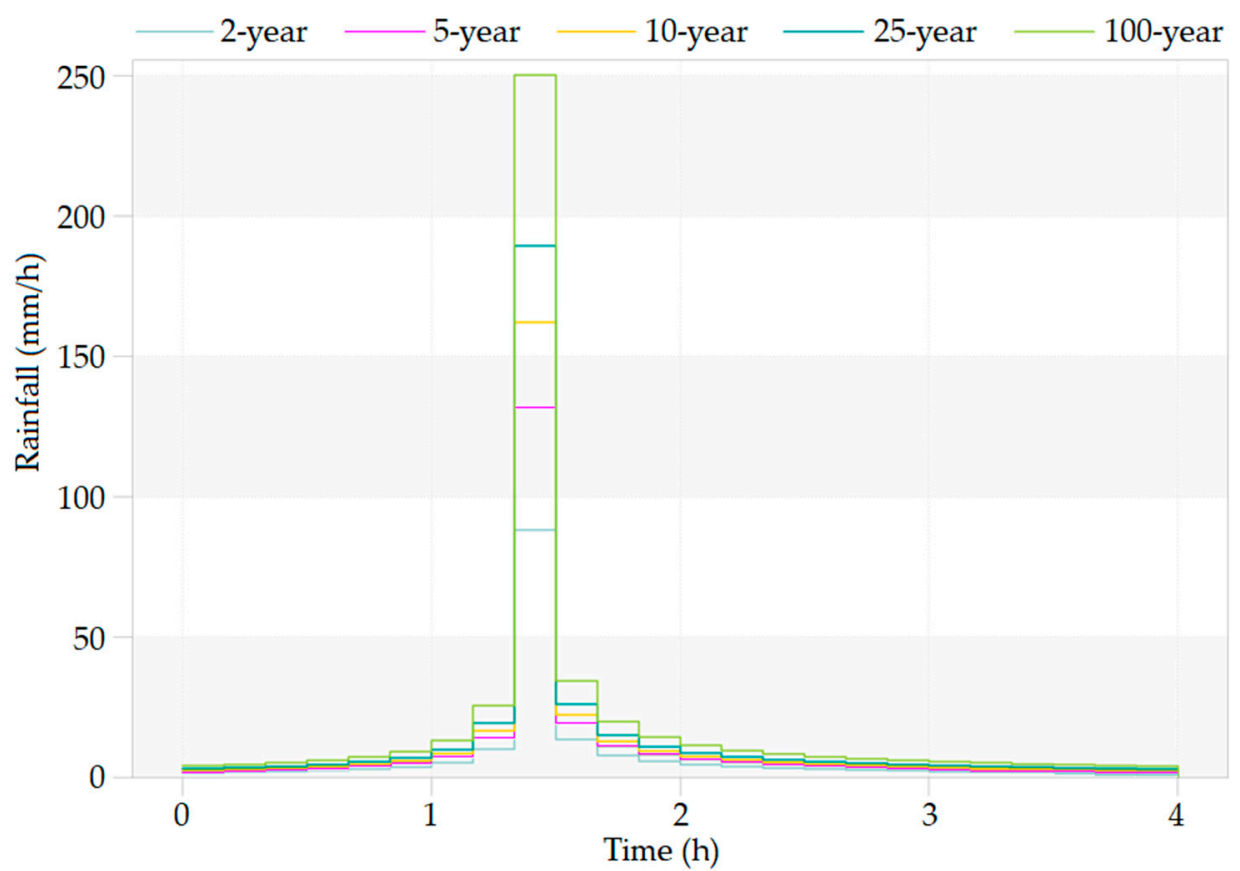

(b)

Figure 5. (a) Toronto Intensity-Duration-Frequency curves; and (b) Chicago Design Storms.

\subsection{Hydraulic Simulations of the Inflow Distribution along an Underground RBR}

As shown in Figure 1, the captured runoff from a storm inlet enters the RBR through an upper perforated pipe. Depending on the perforation size, its orientation around the circumstance, the distance between perforations, and the pipe slope, the runoff can distribute non-uniformly along the pipe. The water profiles under different inflow rates determine the spread of runoff along a RBR. If the water profile ends before the end of the pipe, due to the perforation arrangement, only a partial portion of the RBR is utilized for detention, filtration, and chemical/biological exchange of runoff quantity and quality. In order to maximize the usage of a RBR for runoff management, the perforation arrangement 
should be designed properly to spread the flow throughout a RBR under a design storm condition. Nevertheless, it is seldom considered in the design of an RBR.

The perforated flow distribution pipe is an important feature of LID, including the underground RBR. Duchene and McBean [59] investigated the full pipe discharged characteristics of smooth-wall and corrugated perforated pipes for use in infiltration trenches, and calibrated the orifice coefficient (0.65) of an equivalent orifice with good agreement with experimental measurements. Afrin et al. [60] developed CFD models using the software FLUENT (ANSYS Inc., Canonsburg, PA, USA) to simulate the hydraulic performance of perforated pipe underdrains surrounded by loose aggregates. Liu et al. [61] developed analytical equations for outflow, along the flow in a perforated fluid distribution pipe, based on momentum conservation method. Qin et al. [62] studied the flow velocity distribution along perforated pipes and found the laying slope could be used to promote uniform velocity distribution along the perforated pipes. Paul et al. [63] applied the EPANET software (US Environmental Protection Agency Research, Durham, NC, USA) and assessed discharge uniformity from perforated pipes in constructed wetlands.

All of the above research studies concentrated on full pipe discharge characteristics. On the other hand, this research focuses on the partial flow characteristics of a perforated distribution pipe, resulting in under-utilization of a RBR. A physical hydraulic model was used to collect data for the calibration of a CFD water profile model, which was subsequently used to simulate the flow profiles along an RBR under different inflow conditions.

\subsubsection{Experimental Investigations of Water Profiles along a Perforated Pipe}

A physical hydraulic model was used to analyze the water profiles along a $6.7 \mathrm{~m}$ long section of a $150 \mathrm{~mm}$ corrugated High-Density Polyethylene (HDPE) perforated pipe supplied by Armtec Inc. as per American Association of State Highway and Transportation Officials (AASHTO) M252 Type C standard. Four perforations were cut into the groove of the pipe, at 90 degrees apart, at the factory. Two perforation sizes were investigated: $25 \mathrm{~mm}$ by $25 \mathrm{~mm}$, and $50 \mathrm{~mm}$ by $50 \mathrm{~mm}$. The total number of perforation sets were 275. Additional, the pipe was wrapped in woven geotextile (important for application in the soil layer of a RBR). As shown in Figure 6, the experimental apparatus comprised of an upper reservoir, made of a $30 \mathrm{~cm}$ semi-transparent barrel with a $150 \mathrm{~mm}$ rigid pipe protruding out near the bottom to serve as an outlet. The lower reservoir was made up of four interconnecting plastic water tanks of $1.2 \mathrm{~m}$ in diameter. The perforated pipe was connected to the upstream upper reservoir using a watertight rubber corrugated rigid pipe coupling (Part No.: 1070-66), supplied by Fernco Connectors Ltd. (Sarnia, ON, Canada), while its downstream end was capped using the same coupling. Four piers supported the whole setup, while the perforated pipe was fastened to two by four wood studs by plastic straps. The perforated pipe slope was adjusted to almost level. Water circulation was provided by an IntelliflowXF variable speed pump (Pentair Inc., Minneapolis, MN, USA) through a $50 \mathrm{~mm}$ Poly Vinyl Chloride (PVC) rigid pipe. The flow rate was measured downstream of the pump using a F-1000 paddle wheel flowmeter manufactured by the Blue-White industries, Ltd. (Huntington Beach, CA, USA). As the water level at the upper reservoir rose, the flow inside the perforated pipe exfiltrated through the perforations, collected by a gutter system and returned to the lower reservoir. Four $6 \mathrm{~mm}$ holes were drilled manually at the bottom of the pipe at $1.5 \mathrm{~m}$ apart, starting from the entrance of the perforated pipe. The screw thread at the top of Omega PX309 pressure transducers (Omega Environmental, St-Eustache, QC, Canada) screwed tightly into the four $6 \mathrm{~mm}$ holes and wired to a Sutron 9210 Xlite Data Logger (OTT Hydromet GmbH, Kempten, Germany). Figure 7 shows a photograph of the experimental setup. Repeated measurements of the water depths (at least 3 times) were taken at $5 \mathrm{~min}$ intervals up to $20 \mathrm{~min}$ along the perforated pipe for flows ranging from 0.63 to $10.28 \mathrm{~L} / \mathrm{s}$. The measured water profiles under different inflows were used to calibrate a water profile simulation model described in the next subsection. 


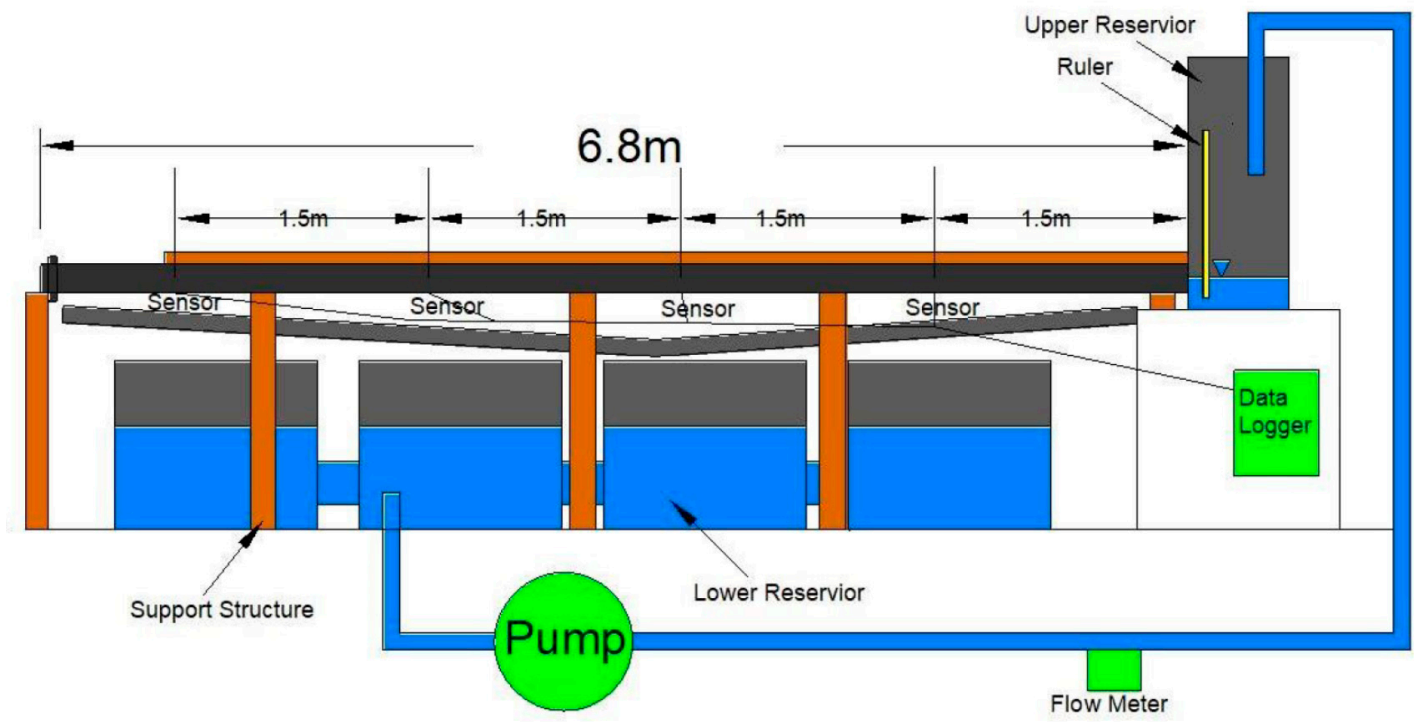

Figure 6. Schematic layout of the exfiltration pipe experimental apparatus.

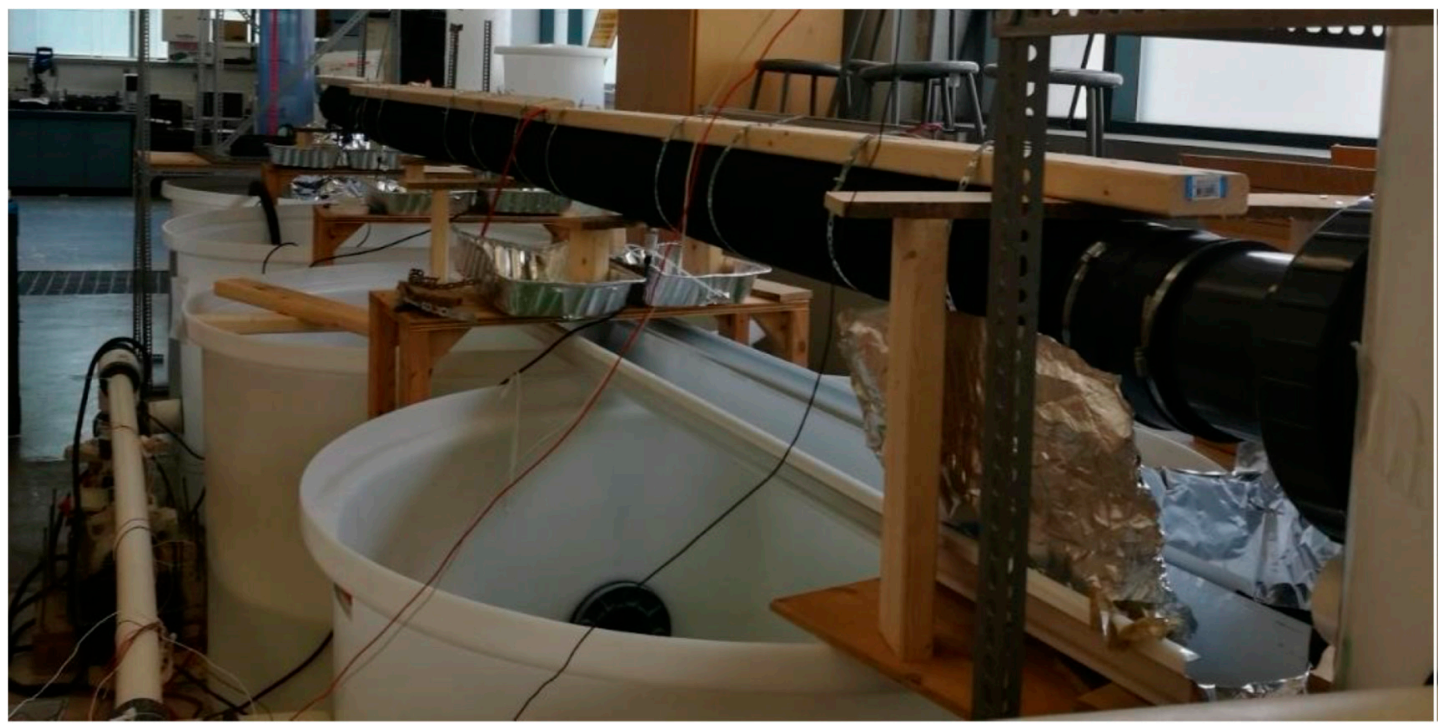

Figure 7. Photograph of the experimental apparatus.

\subsubsection{CFD Simulation of Water Profiles Long a Perforated Pipe}

The FLOW-3D software [64] (Flow Science Inc., Santa Fe, NM, USA) was used to model the water profiles along the experimental perforated pipe under five inflow rates (from 0.62 to $10.28 \mathrm{~L} / \mathrm{s}$ ). Based on the finite-volume method, the Reynolds-averaged Navier Stokes equation was solved by the FLOW-3D. The computational domain of the pipe was divided into rectangular three dimensional computational grid of cells. The geometry of the perforated pipe and the perforations were drawn by AutoCAD-3D and imported to the FLOW-3D software. A large block of mesh was applied for the entire perforated pipe and small meshes were used for the perforation area. Since two-phase simulations were not used, the boundary condition in this research was the inner wall of the perforated pipe. The FLOW-3D model was calibrated using the measured water profiles in the experiments. The calibrated FLOW-3D model was then used to simulate the lengths of the partially filled perforated pipe of the Toronto RBR under different inflow rates. These simulated lengths were then used to determine the outflow adjustments for the Toronto RBR under partial inflow distribution conditions. 
2.3. Overall Runoff Control Performance Analysis of a RBR with Outflow Adjustment for the Partially Filled Distribution Pipe

Many hydrologic models, which were developed to simulate the runoff control performance of RBR, were based on the assumption of a fully utilized RBR [27-29,40-44]. Depending upon the inflow rate, the inflow may, or may not, reach the full length of a RBR. For the underground RBR in Figure 1, it is important to determine the critical inflow rate at which the water profile will extend to the full length of a RBR, resulting in the full utilization of a RBR for runoff control. Any inflow less than this critical inflow rate will affect the runoff control performance because only a fraction of the RBR will be utilized for runoff control.

The calibrated CFD model, described in the previous subsection, was used to determine the critical inflow rate of the Toronto RBR at which the inflow would spread over the entire length of the perforated distribution pipe. Using the dual drainage model described in Section 2.1, the outflow hydrographs of different effective lengths of the Toronto RBR were analyzed. If the inflow rate of the RBR was less the critical inflow rate, the outflow hydrograph of a partially utilized RBR was used. Otherwise, the outflow hydrograph of the fully utilized RBR was adopted. Finally, the overall runoff control performance (e.g., volume and peak flow controlled) for different design storm conditions was determined by comparing the total runoff and the adjusted outflow hydrographs of the RBR.

\section{Results}

For the Toronto RBR case study, the integrated hydraulic and hydrologic approach was used to investigate: (1) Effect of catch basin types on the bypassed and captured runoff hydrographs and the runoff control performance; and (2) effect of inflow distribution on the overall runoff control performance.

\subsection{Effect of Catch Basin Types on the Bypassed and Captured Runoff Hydrographs}

Four types of inlets [65] were investigated for the $18 \mathrm{~m}$ long RBR: (a) single horizontal bar/fishbone catch basins; (b) OPSD400.01 catch basin; (c) single and twin grid catch basins; and (d) single and twin honeycomb catch basins. The PCSWMM model developed for the Toronto RBR was used to analyze (1) the bypassed and captured hydrographs at the catch basin; (2) the inlet and outlet hydrographs of the RBR; and (3) the peak runoff rate reduction (i.e., \% reduction of the peak runoff rate) and the runoff volume controlled (\% reduction of the total runoff volume) of the RBR for different design storms.

\subsubsection{Single and Twin Horizontal Bar/Fishbone Catch Basins}

Figure 8 shows the inlet and outlet hydrographs of the RBR and the bypassed hydrograph at the catch basin for 4-h design storms of 2 to 100 year return periods. The bypassed hydrographs (Figure 8b) of 2-, and 100-year storms have peak flow rates 2 and 10 times higher than those of the inlet hydrographs (Figure 8a). The peak runoff, captured by the catch basin, occurs after almost 90 min for all storms, while the peak outflow occurs after $8 \mathrm{~h}$ and $6 \mathrm{~h}$ for 2-, and 100-year storms, respectively. The peak outflow from the RBR is about $0.4 \mathrm{~L} / \mathrm{s}$ for a 2 -year storm, since the soil percolation rate reaches the hydraulic conductivity of loamy sand soil of $30 \mathrm{~mm} / \mathrm{h}$. For all storms, it takes almost $72 \mathrm{~h}$ for runoff to drain out of the RBR. As shown in Table 4, the peak runoff rate reduction and the runoff volume controlled are about $24 \%$ and $36 \%$ and $13 \%$ and $33 \%$ for $2-$, and $100-$ year storms, respectively. Most of the runoff bypasses the catch basin, resulting in relatively low runoff control performance. 


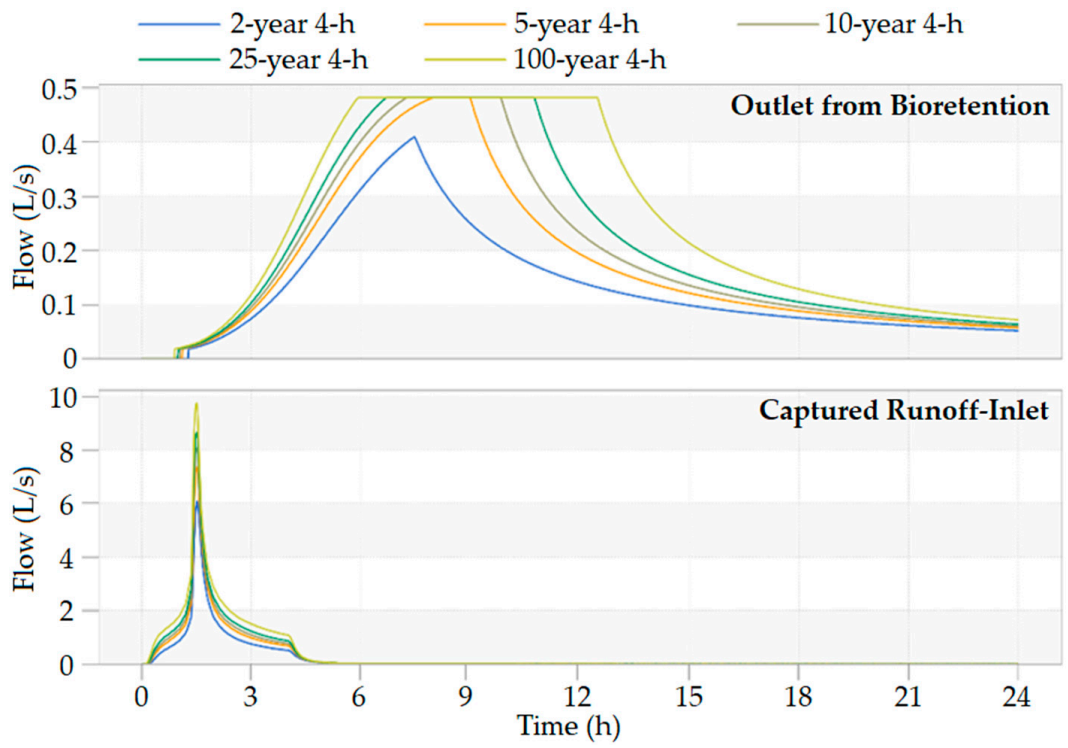

(a)

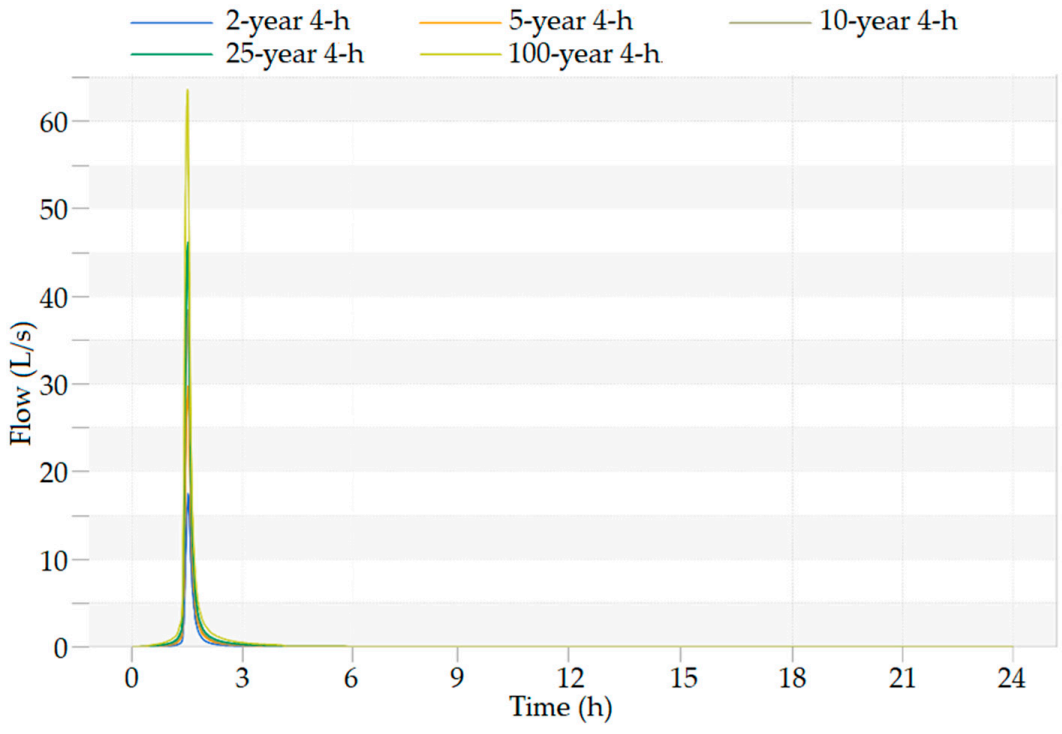

(b)

Figure 8. Hydrographs of a single and twin horizontal bar/fishbone catch basin; (a) inlet and outlet hydrographs; and (b) bypassed hydrographs.

Table 4. Runoff control performances of single \& twin horizontal bar/fishbone catch basin.

\begin{tabular}{cccccc}
\hline $\begin{array}{c}\text { Single \& Twin Horizontal } \\
\text { Bar/Fishbone Catch Basins }\end{array}$ & 2-Year & 5-Year & 10-Year & 25-Year & 100-Year \\
\hline Peak Runoff Rate Reduction (\%) & 24.3 & 20.2 & 17.8 & 16.6 & 12.6 \\
\hline Runoff Volume Controlled (\%) & 35.6 & 32.8 & 32.2 & 32.1 & 32.8 \\
\hline
\end{tabular}

\subsubsection{OPSD400.01 Catch Basins}

Figure 9 shows the inlet and outlet hydrographs of the RBR and the bypassed hydrograph at the catch basin for 4-h design storms of 2 to 100 year return periods. The bypassed hydrographs (Figure 9b) of 2-, and 100-year storms have peak flow rates 6.5 and 13.6 times higher than those of the inlet hydrographs (Figure 9a). The peak runoff captured by the catch basin occurs after almost 90 min 
for all storms while the peak outflow occurs after $5.5 \mathrm{~h}$ and $8 \mathrm{~h}$ for 2-, and 100-year storms, respectively. For this catch basin, the soil percolation rate does not reach the hydraulic conductivity of loamy sand soil. As shown in Table 5, the peak runoff rate reduction and the runoff volume controlled are about $13 \%$ and $43 \%$ and $7 \%$ and $34 \%$ for $2-$, and 100 -year storms, respectively. Most of the runoff bypasses the catch basin, resulting in relatively low runoff control performance.

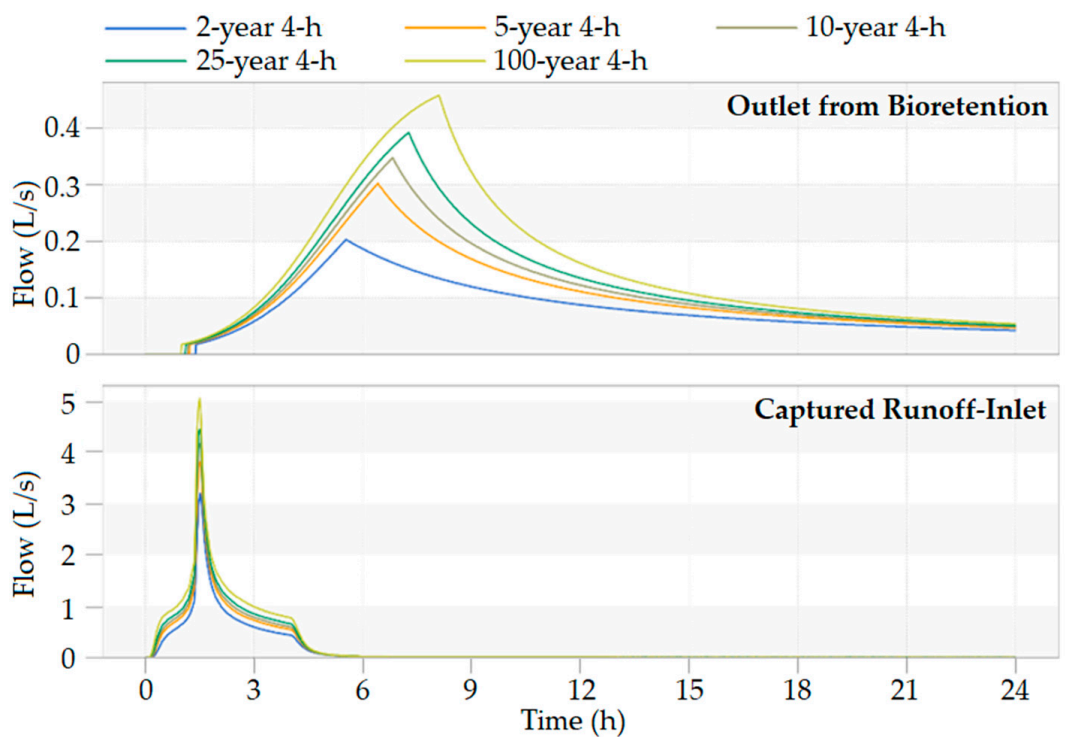

(a)

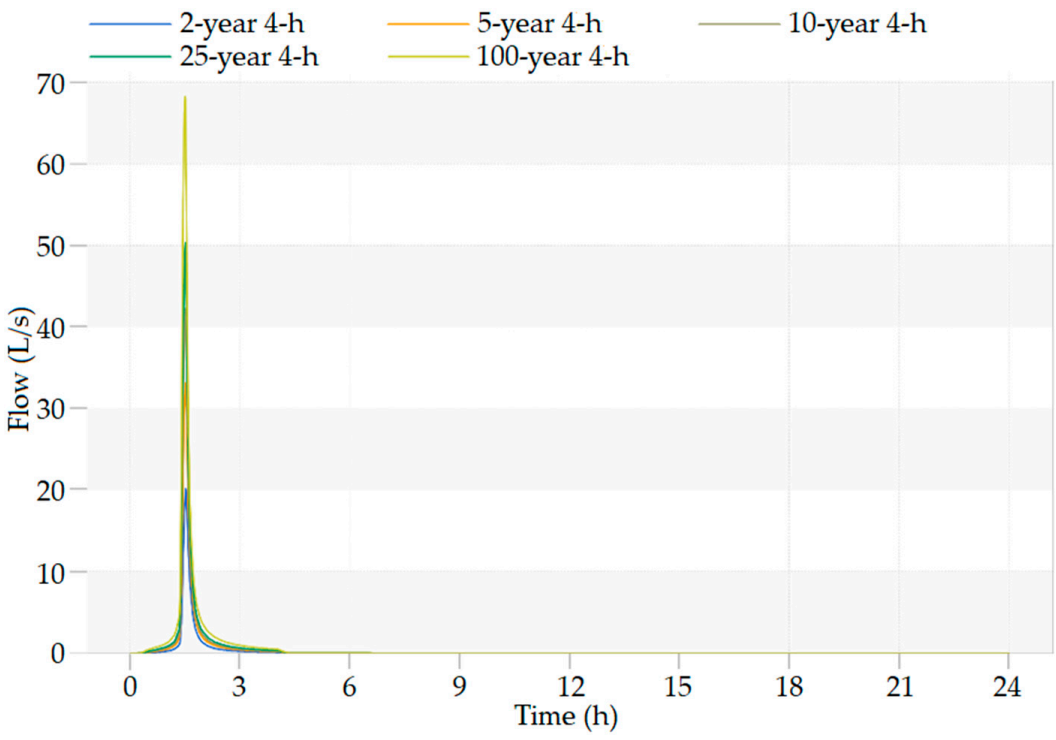

(b)

Figure 9. Hydrographs of an OPSD400.01 catch basin (a) inlet and outlet hydrographs; and (b) bypassed hydrographs.

Table 5. Runoff control performances of OPSD400.01 catch basin.

\begin{tabular}{cccccc}
\hline OPSD400.01 Catch Basin & 2-Year & 5-Year & 10-Year & 25-Year & 100-Year \\
\hline Peak Runoff Rate Reduction (\%) & 13.4 & 10.1 & 9.1 & 8.2 & 7.1 \\
\hline Runoff Volume Controlled (\%) & 42.8 & 38.8 & 37.2 & 35.8 & 33.7 \\
\hline
\end{tabular}




\subsubsection{Single and Twin Grid Catch Basins}

Figure 10 shows the inlet and outlet hydrographs of the RBR and the bypassed hydrograph at the catch basin for 4-h design storms of 2 to 100 year return periods. The bypassed hydrographs (Figure 10b) of 2-, and 100-year storms have peak flow rates 3.2 and 7.3 times higher than those of the inlet hydrographs (Figure 10a). The results of this type are similar to that of the horizontal bar/fishbone catch basins. The maximum peak outflow is $0.48 \mathrm{~L} / \mathrm{s}$ when the soil percolation rate reaches the hydraulic conductivity of loamy sand soil. As shown in Table 6, the peak runoff rate reduction and the runoff volume controlled are about $22 \%$ and $36 \%$ and $13 \%$ and $32 \%$ for $2-$, and $100-$ year storms, respectively. Most of the runoff bypasses the catch basin, resulting in relatively low runoff control performance.

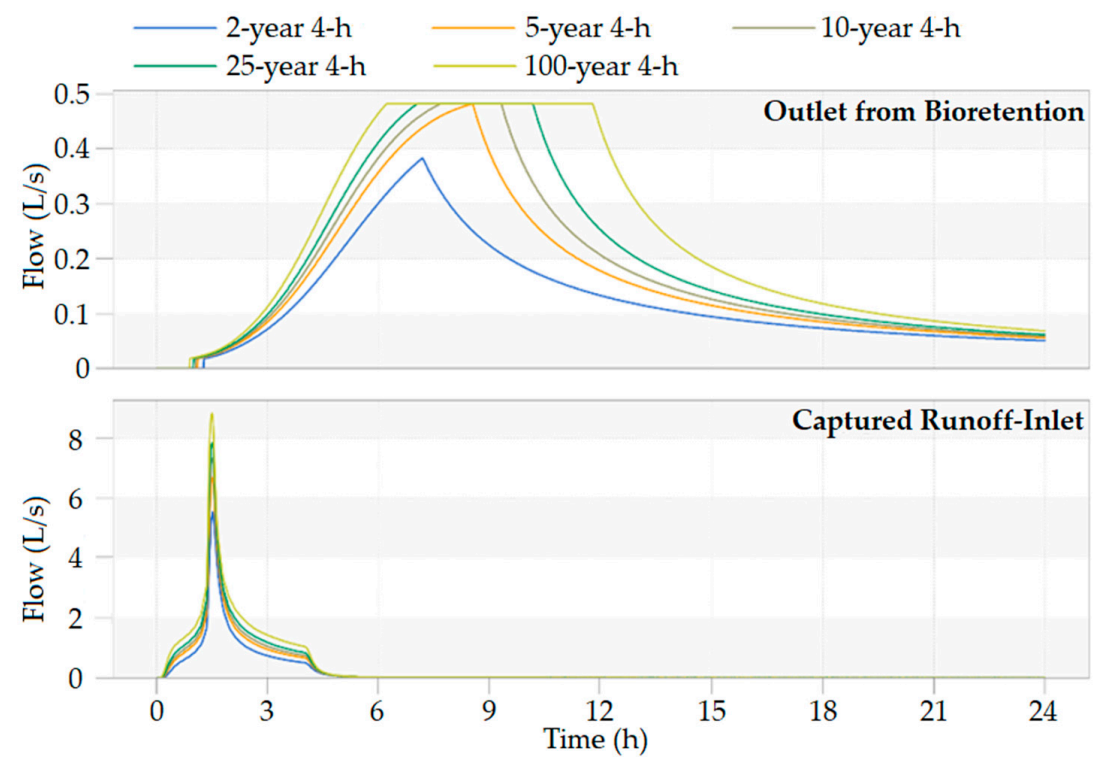

(a)

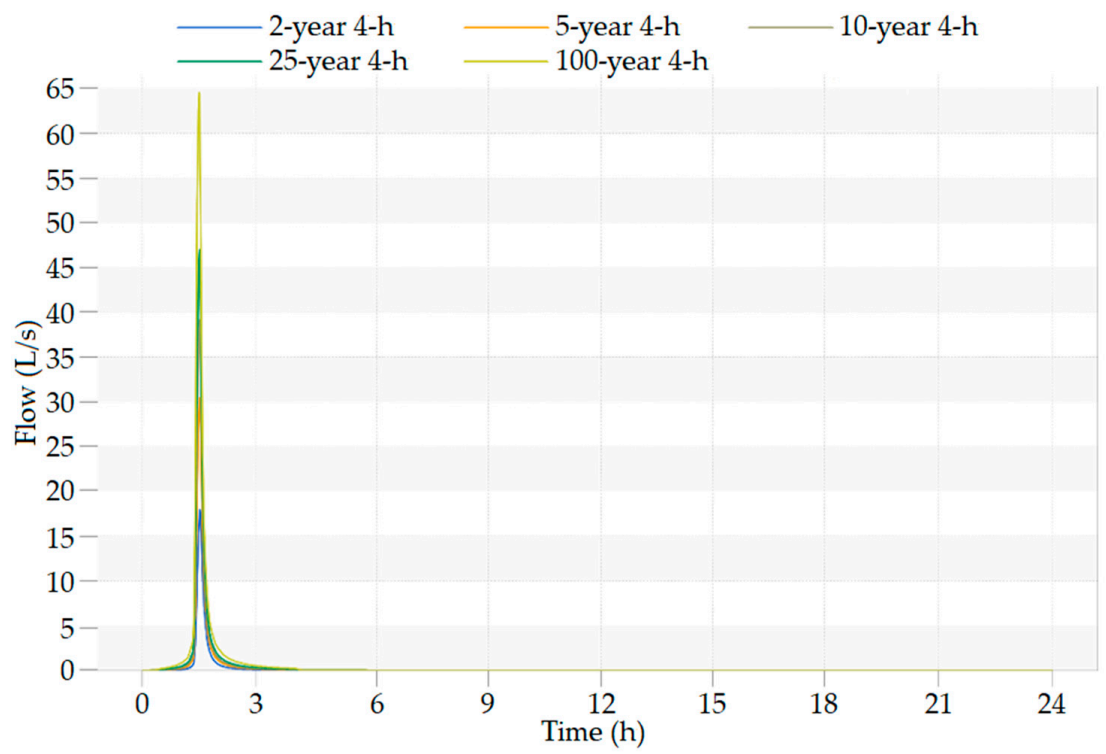

(b)

Figure 10. Hydrographs of a single and twin grid catch basin (a) inlet and outlet hydrographs; and (b) bypassed hydrographs. 
Table 6. Runoff control performances of single and twin grid catch basin.

\begin{tabular}{cccccc}
\hline Single \& Twin Grid Catch Basins & 2-Year & 5-Year & 10-Year & 25-Year & 100-Year \\
\hline Peak Runoff Rate Reduction (\%) & 22.2 & 17.8 & 16.1 & 14.2 & 12.5 \\
\hline Runoff Volume Controlled (\%) & 36.4 & 33.2 & 32.5 & 32 & 32.3 \\
\hline
\end{tabular}

\subsubsection{Single and Twin Honeycomb Catch Basins}

Figure 11 shows the inlet and outlet hydrographs of the RBR and the bypassed hydrograph at the catch basin for 4-h design storms of 2- to 100-year return periods. The bypassed hydrographs (Figure 11b) of 2-, and 100-year storms have peak flow rates 6 and 15 times higher than those of the inlet hydrographs (Figure 11a). This honeycomb catch basin has a high capacity for capturing runoff compared to that of horizontal bar and grid catch basins. The peak outflows range from 0.15 to $0.45 \mathrm{~L} / \mathrm{s}$. As shown in Table 7, the peak runoff rate reduction and the runoff volume controlled are about $12 \%$ and $44 \%$ and $6 \%$ and $35 \%$ for 2-, and 100-year storms, respectively. Most of the runoff bypasses the catch basin, resulting in relatively low runoff control performance.

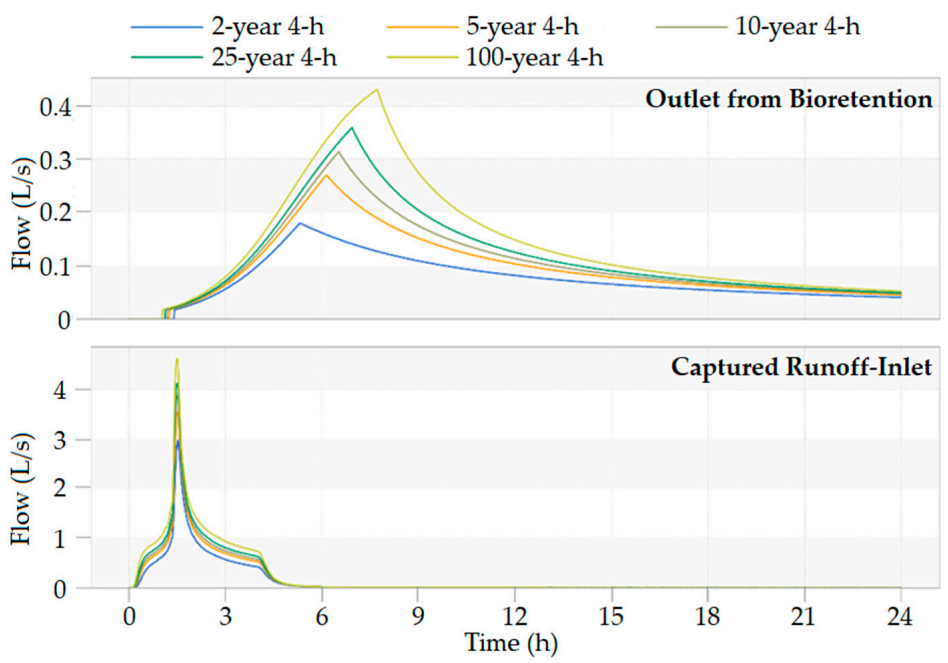

(a)

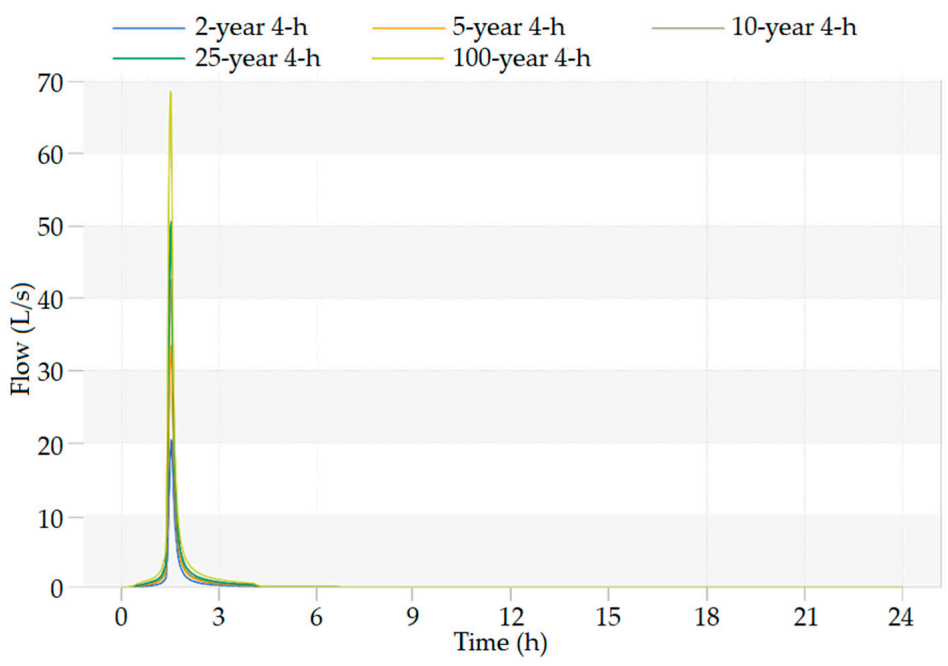

(b)

Figure 11. Hydrographs of a single and twin honeycomb catch basin; (a) inlet and outlet hydrographs; and (b) bypassed hydrographs. 
Table 7. Runoff control performances of single and twin honeycomb catch basin.

\begin{tabular}{cccccc}
\hline Single \& Twin Honeycomb Catch Basins & 2-Year & 5-Year & 10-Year & 25-Year & 100-Year \\
\hline Peak Runoff Rate Reduction (\%) & 12.3 & 9.6 & 7.9 & 7.6 & 6.3 \\
\hline Runoff Volume Controlled (\%) & 43.9 & 39.9 & 38.3 & 36.8 & 34.5 \\
\hline
\end{tabular}

\subsubsection{Performance Comparison of All Catch Basins}

Among the four types of catch basins, the single and twin horizontal bar/fishbone catch basin performs the best with the highest peak flow reduction, while the single and twin honeycomb catch basin performs the best with the highest runoff volume controlled. By comparing the inlet and outlet hydrographs of horizontal bar/fishbone catch basin (Figure 8) with those of the honeycomb catch basin (Figure 11), it is clear that the peak inlet flow (6 L/s for a 2-year storm) of the fishbone catch basin is greater than that $(3 \mathrm{~L} / \mathrm{s}$ for a 2-year storm) of the honeycomb catch basin, resulting in higher peak flow reduction. Fishbone catch basin has a higher interception capacity (e.g., $0.014 \mathrm{~m}^{3} / \mathrm{s}$ at $0.065 \mathrm{~m}$ head) than that $\left(0.005 \mathrm{~m}^{3} / \mathrm{s}\right.$ at $0.065 \mathrm{~m}$ head) of the honeycomb catch basin [65]. On the other hand, the outlet hydrograph of the fishbone catch basin has larger volume (Figure 8) than that (Figure 11) of the honeycomb catch basin, resulting in lower runoff volume controlled. Nevertheless, none of the catch basins can intercept sufficient runoff to the RBR, resulting in runoff control performance of the RBR less than $45 \%$ for a 2 -year storm (Tables $4-7$ ).

\subsection{Effect of Inflow Distribution on the Overall Runoff Control Performance of the RBR}

Effective length of a RBR, defined as the extent at which the captured runoff at a catch basin is distributed along a RBR, affect the overall runoff control performance. It depends upon the inflow rate and the perforation arrangement of the inflow distribution pipe. The calibration of the FLOW-3D model was based on (1) mesh sizes of the pipe and the perforations; (2) physics model coefficients such as the turbulence mixing length parameter; (3) boundary conditions such the pipe alignment and perforation locations; and (4) options for volume-of-fluid methods. An accepted goodness of fit criterion of $15 \%$ was also assumed to account for the uncertainty of the experimental pipe inner wall boundary and slope, perforation size, orientation, spacing, and level and flow sensors. As indicated in Figure 12, the measured water profiles along the perforated pipe (with $25 \mathrm{~mm}$ sized perforations) are non-uniform and the FLOW-3D model simulated water profiles generally match the laboratory measurements (within 10-15\%) over the test flow range of 0.63 to $10.28 \mathrm{~L} / \mathrm{s}$. For lower inflows (less than $8.08 \mathrm{~L} / \mathrm{s}$ ), the goodness of fit between the measured and the simulated water profiles are consistent. Under the partially surcharged condition (at $10.28 \mathrm{~L} / \mathrm{s}$ ), there is a clear discrepancy between the measured and modelled water profile near the entrance. Given the focus of this study is the free surface water profiles, the calibration is considered acceptable.

The calibrated FLOW-3D model was used to simulate water profiles along the inflow distribution pipe of the Toronto RBR under different inflow rate conditions. The Toronto RBR's inflow distributed pipe has the following characteristics: $150 \mathrm{~mm}$ perforated pipe with a total length of $18 \mathrm{~m}, 19$ sets of $10 \mathrm{~mm}$ perforations at a distance of $0.9 \mathrm{~m}$ apart. Figure 13 shows the simulated water profiles ranging from 2 to $10 \mathrm{~L} / \mathrm{s}$. It is noted that the water profiles at $4 \mathrm{~L} / \mathrm{s}$ or below are gradually varied and do not distribute over the whole length of the pipe. The critical (minimum) inflow, which distributes fully and non-uniformly over the $18 \mathrm{~m}$ was found to be about $6 \mathrm{~L} / \mathrm{s}$. Two alternative effective lengths, $12 \mathrm{~m}(67 \%$ of $18 \mathrm{~m})$ and $16 \mathrm{~m}(88 \%$ of $18 \mathrm{~m})$, and the full length (i.e., 100\%) of the inflow pipe were investigated for the Toronto RBR using the dual drainage PCSWMM model. Figure 14 shows the inflow and outflow hydrographs of 100\% (18 m), 88\% (16 m), 67\% (12 m) of the RBR. For the 2-year design storm (Figure 14a), the inflow hydrograph was increasingly attenuated as the effective length increases (i.e., $67 \%>88 \%>100 \%$ ). However, the effect of different effective lengths on the outflow hydrograph is negligible for the 5-year design storm (Figure 14b). Since the difference between the $16 \mathrm{~m}$ and $18 \mathrm{~m}$ outflow hydrographs is relatively small, the outflow hydrograph of $12 \mathrm{~m}$ (67\% of the 
full length) was used to represent the outflow hydrograph for inflow rate less than $6 \mathrm{~L} / \mathrm{s}$. As shown in Figure 15 , the blue columns are the times that $100 \%$ of the RBR would be utilized. The captured inflow only exceeded $6 \mathrm{~L} / \mathrm{s} 2$ times for the 2-year storm and 14 times for the 100-year storm. As a result, the outflow hydrographs for 2-, and 100-year storms were adjusted to 67\% effective length for those time periods less than $6 \mathrm{~L} / \mathrm{s}$ while the rest of the outflow hydrographs were assumed to be $100 \%$ full length. For the 2-year storm condition, the peak flow reduction and the runoff volume controlled of RBR with outflow adjustment are about $2 \%$ less than those without outflow adjustment. There is negligible difference for the 100-year storm condition.

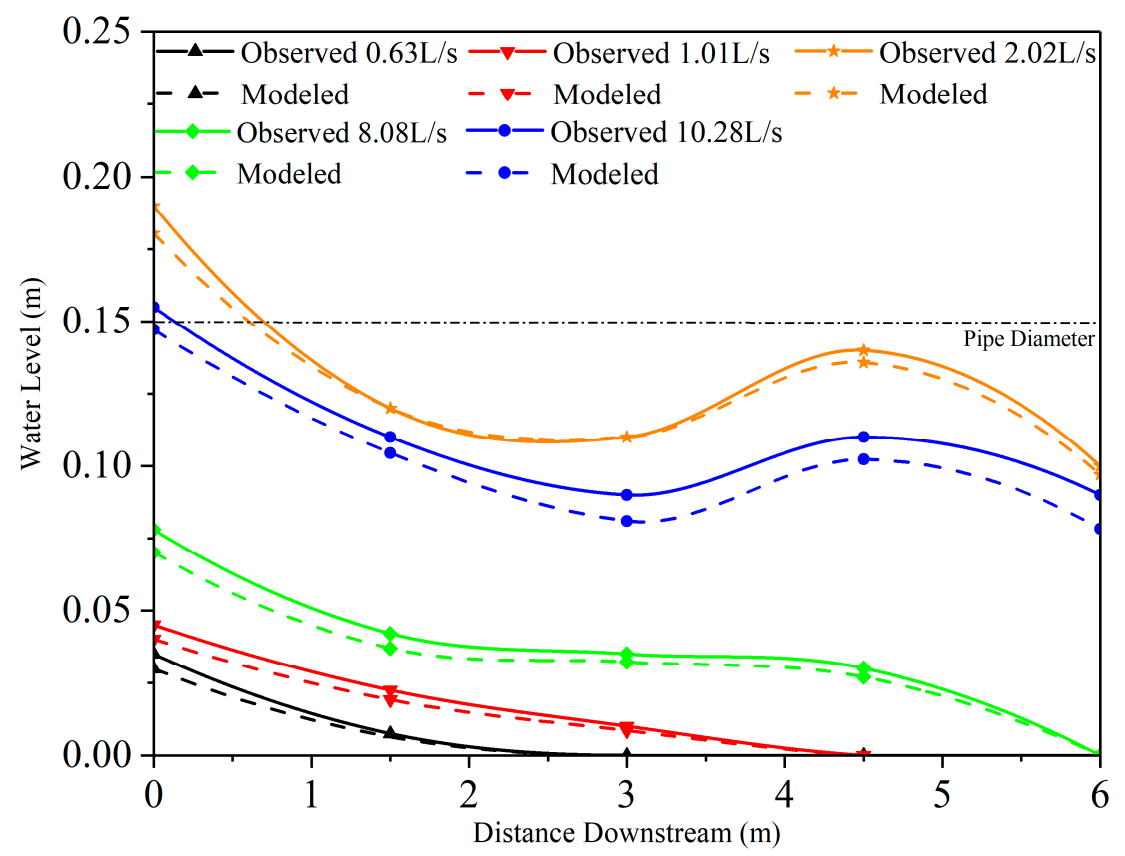

Figure 12. Comparison of the FLOW-3D model simulations with the experimental results.

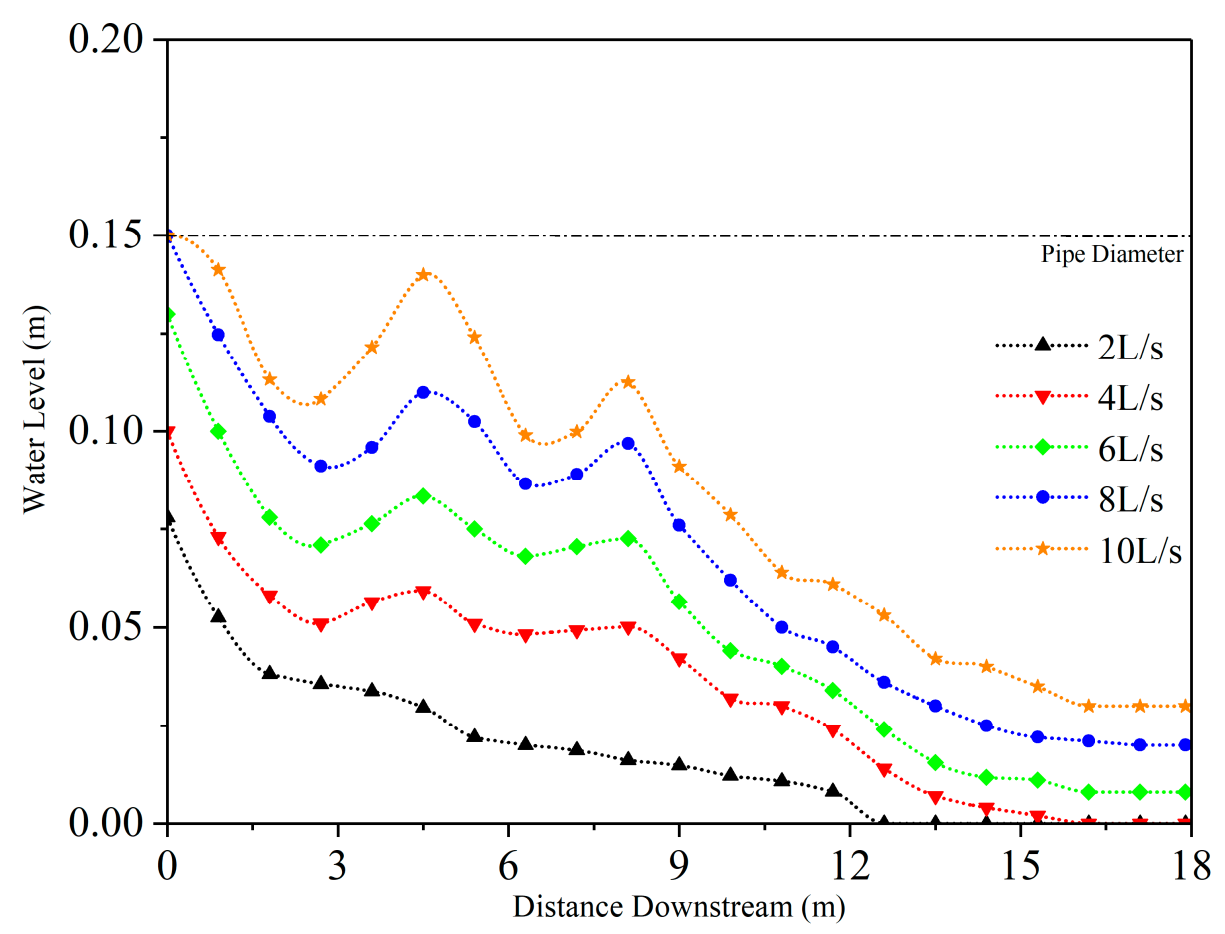

Figure 13. Water profiles for various inflow rates. 


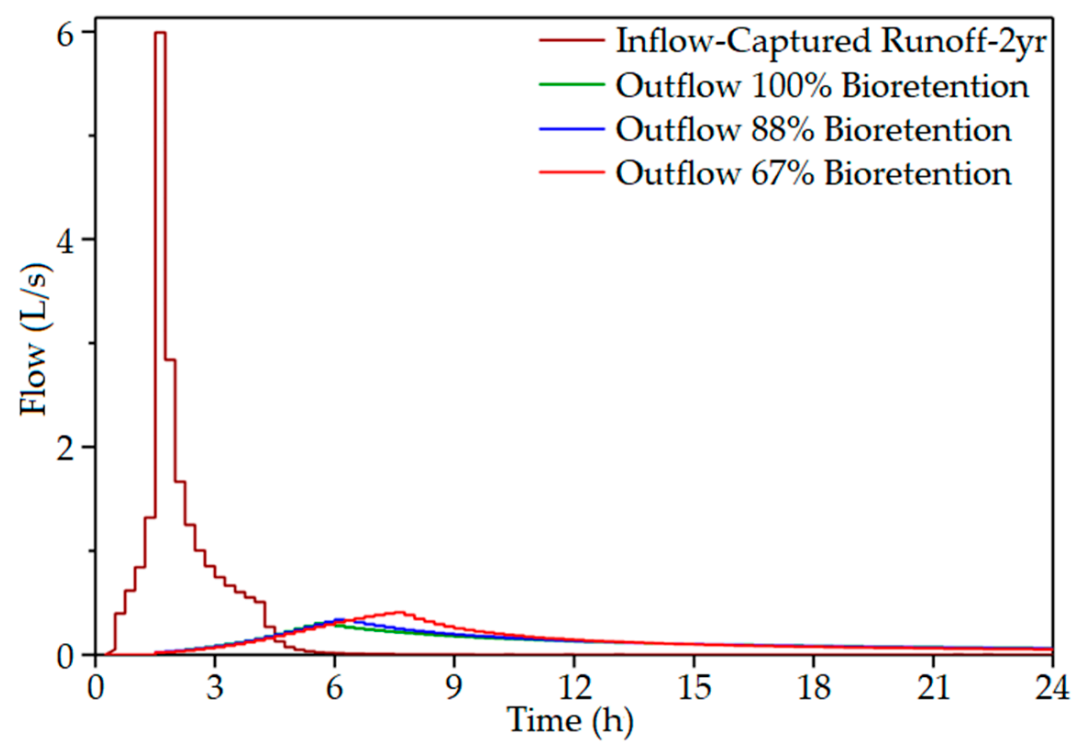

(a)

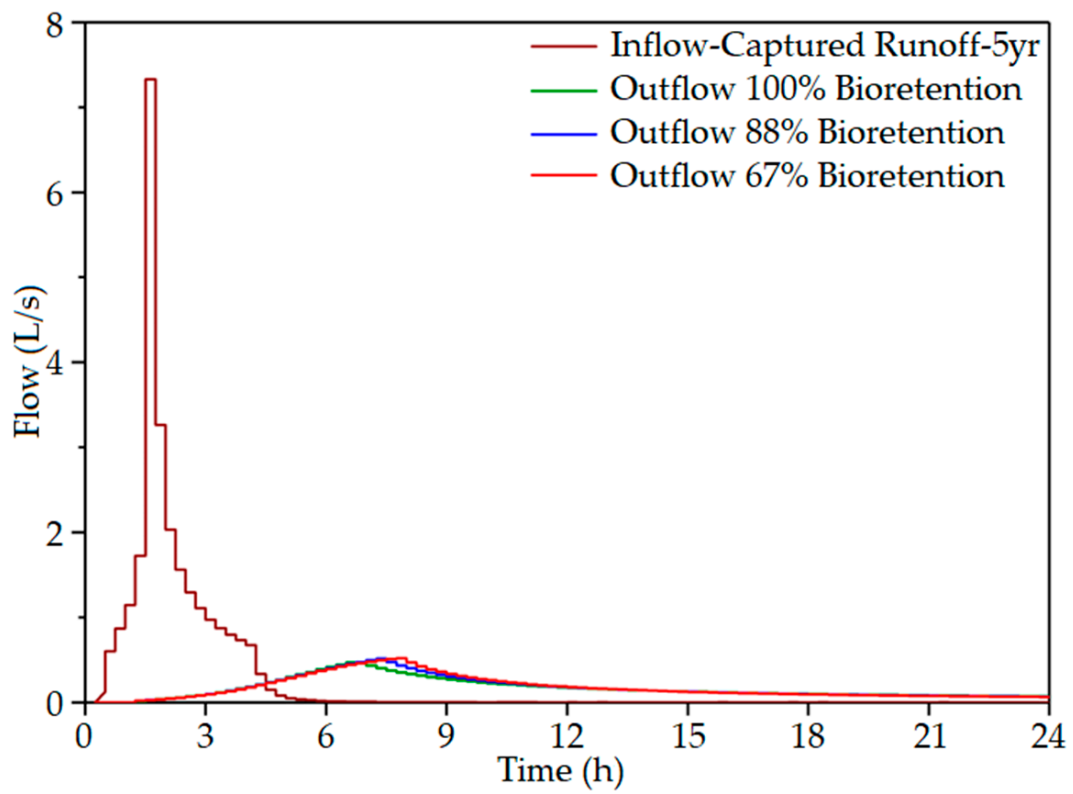

(b)

Figure 14. Inflow and outflow hydrographs of RBR for 12, 16, $18 \mathrm{~m}$ of length (a) 2-year; (b) 5-year. 


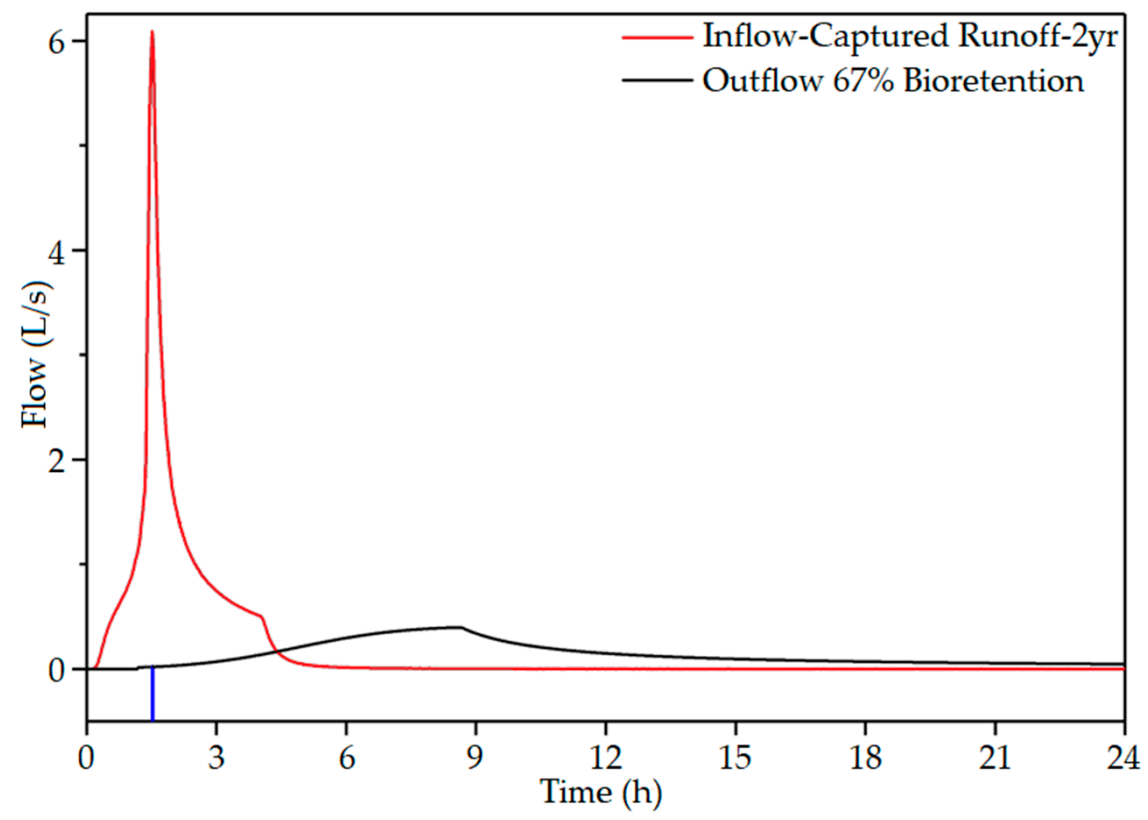

(a)

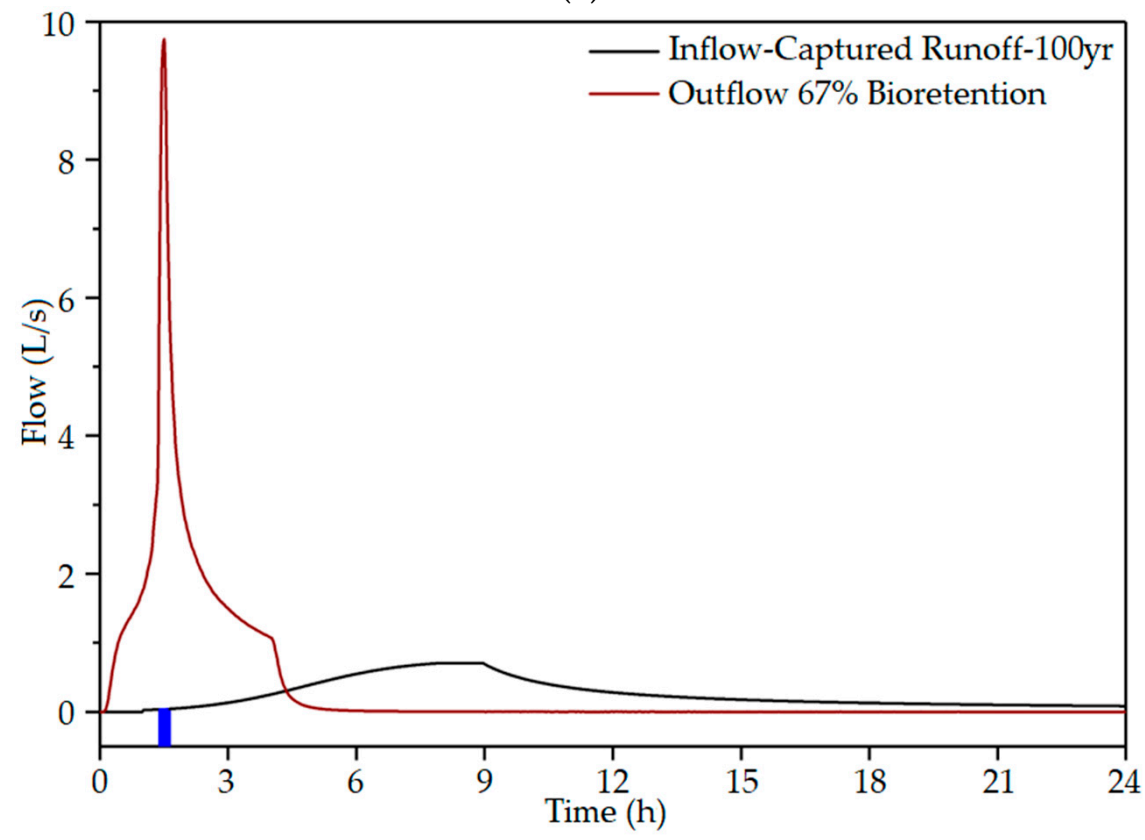

(b)

Figure 15. The modified inflow and outflow hydrographs for; (a) 2-year storm; (b) 100-year storm.

\section{Discussion}

The first investigation of catch basin effects has demonstated the importance of a catch basin inlet on the overall runoff control performance of a RBR. Although, the number of catch basins along a road are designed to match the drainage capacity of a storm sewer (e.g., runoff of a 2-year storm), an underground RBR is typically aligned with one catch basin. For the four types of catch basins in the Toronto case study, the peak flow rate reduction and the runoff volume controlled for 100-, and 2-year design storms were $12-24 \%$, and $36-44 \%$, respectively because the majority of the runoff bypassed the inlet of the RBR. This case study finding is similar to the intercepting efficiency (35-48\%) simulated by 
a detailed two-dimensional (2D) overland flow simulation model FullSWOF_2D (with grate-inlet and one-dimensional pipe flow) and 20 storm inlet monitored results reported by Li et al. [56].

The second investigation of effective length or effective utilization of a RBR has indicated that water profiles along the inflow distribution pipe can be spatially varied and the hydraulics of inflow distribution pipe affects the runoff control performance of a RBR. However, the inflow pipe characteristics (e.g., number and size of perforations, distance between perforations) of the Toronto RBR do not cause a significant difference of the runoff peak flow reduction and the runoff volume controlled ( $2 \%$ difference for a 2-year storm and negligible difference for a 100-year storm) even the effective length of the RBR was taken into consideration.

\section{Conclusions and Recommendations}

Based on the aforementioned research, the following conclusions are drawn and recommendations are suggested:

1. No matter how well a RBR is designed (e.g., soil porosity, types of soil, and other outlet features), the inlet dictates its overall runoff control performance. Catch basins are storm inlets and their intercepting capacities vary according to their design (longitudinal and cross slope of road, grate openings and orientation, curb openings). In order to capture more runoff to a RBR, double curb and grate catch basins or multiple inlets should be considered. Recent research studies $[49,53,54]$ also indicate that the traditional hydraulic calculations of catch basin efficiencies may not be adequate. Thus, future investigations of RBR performance should update the traditional inlet efficiency curves of currently available catch basins.

2. The overall runoff control performance of RBR is dependent upon the distribution of inflow over the RBR. In order to fully utilize a RBR, a detailed hydraulic analysis of the inflow distribution pipe, including the perforation size, orientation, spacing, should be performed. Although the case study does not show any significant difference in runoff control performance between the partially and fully utilized RBR, there are situations in which the partially utilized RBR may be important. For instance, if the perforation size is large and their spacing is short, short-curcuiting of flow through the RBR may occur, resulting in large periods of partially utilized RBR and low runoff control performance. Perforated pipes are increasing used as conveyanace and exfiltration components in LIDs, such as grass swale-perforated pipes [66], infiltration trenches [59], exfiltration storage systems [6] and bioretentions [7]. Unfortunately, detailed perforated pipe hydraulic analyses $[60,61]$ are rarely considered in LID modeling. Future research of RBR should not only focus on the associated chemical and biological processes but also the hydraulics of flows at the inlet and perforated distribution pipes.

Author Contributions: Conceptualization, J.L. and D.J.; Methodology, J.L. and D.J.; Software, S.A.; Validation, S.A. and L.C.; Formal Analysis, S.A. and L.C.; Investigation, S.A. and L.C.; Data Curation, S.A. and L.C.; Writing-Original Draft Preparation, J.L.; Writing-Review \& Editing, J.L.; Visualization, S.A. and L.C.; Supervision, J.L. and D.J.; Project Administration, J.L.; Funding Acquisition, J.L. All authors have read and agreed to the published version of the manuscript.

Funding: This research was funded by Natural Science and Engineering Research Council, Discovery Grant Number (1-51-50068).

Acknowledgments: The authors would like to acknowledge the support from Natural Science and Engineering Research Council, the City of Toronto, Flow Science Inc., Armtec Inc., Computational Hydraulics International.

Conflicts of Interest: The authors declare no conflict of interest. The founding sponsors had no role in the design of the study; in the collection, analyses, or interpretation of data; in the writing of the manuscript, and in the decision to publish the results. 


\section{References}

1. Li, J.; Banting, D.; Joksimovic, D.; Fan, C.; Eric, M.; Lawson, S.; Ahmed, N.; Hahn, K.; Mirzajani, M. Evaluation of Low Impact Development Stormwater Technologies for the Uncontrolled Urban Areas in the Lake Simcoe. In A Report Prepared the Lake Simcoe Region Conservation Authority; Ryerson University: Toronto, ON, Canada, 2010.

2. Low Impact Development Center, Inc. Introduction to LID: Frequently Asked Questions. In LID Urban Design Tools. 2007. Available online: http://www.lid-stormwater.net/index.html (accessed on 22 February 2019).

3. Transportation Association of Canada. Geometric Design Guide for Canadian Roads; Transportation Association of Canada: Ottawa, ON, Canada, 2017.

4. Alam, M.D.; Anwar, A.H.M.; Heitz, A.; Sarker, D.C. Improving Stormwater Quality at Source using Catch Basin Inserts. J. Environ. Manag. 2018, 228, 393-404. [CrossRef] [PubMed]

5. Alam, M.D.; Anwar, A.H.M.; Sarker, D.C.; Heitz, A.; Rothleitner, C. Characterising Stormwater Gross Pollutants Captured in Catch Basin Inserts. J. Environ. Manag. 2017, 586, 76-86. [CrossRef] [PubMed]

6. Li, J.; Joksimovic, D.; Tran, J. A Right-of-Way Stormwater Low Impact Development Practice. J. Water Manag. Model. 2015. [CrossRef]

7. Shafique, M. A Review of the Bioretention System for Sustainable Storm Water Management in Urban Areas. Mater. Geoenvironment 2016, 63, 227-235. [CrossRef]

8. Department of Environmental Resources, The Prince George's County, Maryland. Bioretention Manual. 2007. Available online: https://www.slideshare.net/Sotirakou964/md-prince-georges-county-bioretention-manual (accessed on 2 March 2020).

9. Li, J.; Joksimovic, D.; Chen, L. Stormwater Performance Evaluation of Soil Cells. In A Report to the City of Toronto; Ryerson University: Toronto, ON, Canada, 2018.

10. Li, M.-H.; Chan, Y.S.; Kim, M.H.; Chu, K.-H. Assessing Performance of Bioretention Boxes in Hot and Semiarid Regions. Transp. Res. Rec. J. Transp. Res. Board 2011, 2262, 155-163. [CrossRef]

11. Hart, T.D. Root-enhanced Infiltration in Stormwater Bioretention Facilities in Portland, Oregon. Ph.D. Thesis, Portland State University, Portland, Oregon, OH, USA, 2017.

12. Singh, R.P.; Zhao, F.; Ji, Q.; Saravanna, J.; Fu, D. Design and Performance Characterization of Roadside Bioretention Systems. Sustainability 2019, 11, 2040. [CrossRef]

13. Soberg, L.C.; Viklander, M.; Blecken, G.-T. Do Salt and Low Temperature Impair Metal Treatment in Stormwater Bioretention Cells with or without a Submerged One. Sci. Total Environ. 2017, 579, 1588-1599. [CrossRef]

14. Li, Y.; Wen, M.; Li, J.; Chai, B.; Jiang, C. Reduction and Accumulative Characteristics of Dissolved Heavy Metals in Modified Bioretention Media. Water 2018, 10, 1488. [CrossRef]

15. Mullane, J.M.; Flury, M.; Iqbal, H.; Freeze, P.; Hinman, C.; Cogger, C.G.; Shi, Z. Intermittent Rain Storms Cause Pulses of Nitrogen, Phosphorus, and Copper in Leachate from Compost in Bioretention Systems. Sci. Total Environ. 2015, 537, 294-303. [CrossRef]

16. Bjorklund, K.; Li, L. Removal of Organic Contaminants in Bioretention Medium Amended with Activated Carbon from Sewage Sludge. Environ. Sci. Pollut. Res. 2017, 24, 19167-19180. [CrossRef]

17. Blecken, G.-T.; Zinger, Y.; Deletic, A.; Fletcher, T.D.; Hedstrom, A.; Viklander, M. Laboratory Study on Stormwater Biofiltration: Nutrient and Sediment Removal in Cold Temperatures. J. Hydrol. 2010, 394, 507-514. [CrossRef]

18. Rycewicz-Borecki, M.; McLean, J.E.; Dupont, R.R. Nitrogen and Phosphorus Mass Balance, Retention and Uptake in Six Plant Species Grown in Stormwater Bioretention Mirocosms. Ecol. Eng. 2017, 99, 409-416. [CrossRef]

19. Endreny, T.; Burke, D.J.; Burchhardt, K.M.; Fabian, M.W.; Kretzer, A.M. Bioretention Column Study of Bacteria Community Response to Salt-Enriched Artificial Stormwater. J. Environ. Qual 2012, 41, 1951-1959. [CrossRef]

20. Denich, C.; Bradford, A.; Drake, J. Bioretention: Assessing Effects of Winter Salt and Aggregate Application on Plant Health, Media Clogging and Effluent Quality. Water Qual. Res. J. Can. 2013, 48, 387-399. [CrossRef]

21. Taylor, A.; Wetzel, J.; Mudrock, E.; King, K.; Cameron, J.; Davis, J.; McIntyre, J. Engineering Analysis of Plant and Fungal Contributions to Bioretention Performance. Water 2018, 10, 1226. [CrossRef] 
22. Shetterly, B.J. Soil Phosphorus Characterization and Vulnerability to Release in Urban Stormwater Bioretention Facilities. Master's Thesis, Portland State University, Portland, Oregon, OH, USA, 2018.

23. Luell, S.K.; Hunt, W.F.; Winston, R.J. Evaluation of Undersized Bioretention Stormwater Control Measures for Treatment of Highway Bridge Deck Runoff. Water Sci. Technol. 2011, 64, 974-979. [CrossRef]

24. Lacy, S. The Fate of Heavy Metals in Highway Stormwater Runoff: The Characterization of a Bioretention Basin in the Midwest. Master's Thesis, University of Kansas, Lawrence, KS, USA, 2007.

25. Muthanna, T.M.; Viklander, M.; Blecken, G.; Thorolfsson, S.T. Snowmelt Pollutant Removal in Bioretention Areas. Water Res. 2007, 41, 4061-4072. [CrossRef]

26. Kluge, B.; Markert, A.; Facklam, M.; Sommer, H.; Kaiser, M.; Pallasch, M.; Wessolek, G. Metal Accumulation and Hydraulic Performance of Bioretention Systems after Long-term Operation. J. Soils Sediment 2018, 18, 431-441. [CrossRef]

27. Chen, X.; Peltier, E.; Sturm, B.S.M.; Young, C.B. Nitrogen Removal and Nitrifying and Denitrifying Bacteria Quantification in a Stormwater Bioretention System. Water Res. 2013, 47, 1691-1700. [CrossRef]

28. Shrestha, P.; Hurley, S.E.; Wemple, B.C. Effects of Different Soil Media, Vegetation, and Hydrologic Treatments on Nutrient and Sediment Removal in Roadside Bioretention Systems. Ecol. Eng. 2018, 112, 116-131. [CrossRef]

29. Grover, S.P.P.; Cohan, A.; Chan, H.S.; Livesley, S.J.; Beringer, J.; Daly, E. Occasional Large Emissions of Nitrous Oxide and Methane Observed in Stormwater Biofiltration Systems. Sci. Total Environ. 2013, 465, 64-71. [CrossRef]

30. Shrestha, P.; Hurley, S.E.; Adair, E.C. Soil Media $\mathrm{CO}_{2}$ and $\mathrm{N}_{2} \mathrm{O}$ Fluxes Dynamics from Sand-Based Roadside Bioretention Systems. Water 2018, 10, 185. [CrossRef]

31. Kansom, T.; Tedoldi, D.; Gromaire, M.C.; Ramier, D.; Saad, M.; Chebbo, G. Horizontal and Vertical Variability of Soil Hydraulic Properties in Roadside Sustainable Drainage Systems (SuDS)-Nature and Implications for Hydrological Performance Evaluation. Water 2018, 10, 987. [CrossRef]

32. Hunt, W.F.; Lord, B.; Loh, B.; Sia, A. Plant Selection for Bioretention Systems and Stormwater Treatment Practices; Springer: Singapore, 2015; ISBN 9789812872449.

33. Hartung, E.W. Aging Bioretention Cells: Do They Still Function to Improve Water Quality. Master's Thesis, Kent State University, Kent, OH, USA, 2017.

34. Palhegyi, G.E. Modeling and Sizing Bioretention Using Flow Duration Control. J. Hydrol. Eng. 2010, 15, 417-425. [CrossRef]

35. Baek, S.-S.; Ligaray, M.; Park, J.-P.; Shin, H.-S.; Kwon, Y.S.; Brascher, J.T.; Cho, K.H. Developing a Hydrological Simulation Tool to Design Bioretention in a Watershed. Env. Model. Softw. 2017, 1-12. [CrossRef]

36. Zhang, K.; Chui, M.T.F. A Review on Implementing Infiltration-Based Green Infrastructure in Shallow Groundwater Environments: Challenges, Approaches, and Progress. J. Hydrol. 2019, 579, 1-15. [CrossRef]

37. Roy-Poirier, A.; Champagne, P.; Filion, Y. Review of Bioretention System Research and Design: Past, Present, and Future. J. Env. Engrg. ASCE 2010, 136, 878-889. [CrossRef]

38. Gulbaz, S.; Kazezyilmaz-Alhan, C.M. An Evaluation of Hydrologic Modeling Performance of EPA SWMM for Bioretention. Water Sci. Technol. 2017, 76, 3035-3043. [CrossRef]

39. Gao, J.; Pan, J.; Hu, N.; Xie, C. Hydrologic Performance of Bioretention in an Expressway Service Area. Water Sci. Technol. 2018, 77, 1829-1837. [CrossRef]

40. Brown, R.A. Evaluation of Bioretention Hydrology and Pollutant Removal in the Upper Coastal Plain of North Carolina with Development of a Bioretention Modeling Application in DRAINMOD. Ph.D. Thesis, North Carolina State University, Raleigh, NC, USA, 2011.

41. He, Z.; Davis, A. Process Modeling of Storm-Water Flow in a Bioretention Cell. J. Irrig. Drain. Eng. ASCE 2011, 137, 121-131. [CrossRef]

42. Meng, Y.; Wang, H.; Chen, J.; Zhang, S. Modeling Hydrology of a Singel Bioretention System with HYDRUS-1D. Sci. World J. 2014, 1-10. [CrossRef]

43. Stewart, R.D.; Lee, J.G.; Shuster, W.D.; Darner, R.A. Modelling Hydrological Response to a Fully-Monitored Urban Bioretention Cell. Hydrol. Process. 2017, 31, 4626-4638. [CrossRef]

44. Wang, J.; Chua, L.H.C.; Shanahan, P. Hydrological Modeling and Field Validation of a Bioretention Basin. J. Environ. Manag. 2019, 240, 149-159. [CrossRef] [PubMed]

45. Li, W.S.; Sorteberg, K.K.; Geyer, J.C. Hydraulic Behavior of Storm-Water Inlets: II. Flow into Curb-Opening Inlets. Sew. Ind. Wastes 1951, 23, 722-7398. 
46. Li, W.-H.; Goodell, B.C.; Geyer, J.C. Hydraulic Behavior of Storm-Water Inlets: III. Flow into Deflector Inlets. Sew. Ind. Wastes 1954, 26, 836-842.

47. Bock, P.; Li, W.-H.; Geyer, J.C. Hydraulic Behavior of Storm-Water Inlets: V. A Simplified Method of Determining Capacities of Single and Multiple Inlets. Sew. Ind. Wastes 1956, 28, 774-784.

48. Argue, J.R.; Pezzaniti, D. How Reliable are Inlet (Hydraulic) Models at Representing Stormwater Flow. Sci. Total Environ. 1996, 180/190, 355-359. [CrossRef]

49. Guo, J.C.Y.; MacKenzie, K.A.; Mommandi, A. Design of Street Sump Inlet. J. Hydraul. Eng. ASCE 2009, 135, 1000-1004. [CrossRef]

50. Gomez, M.; Recasens, J.; Russo, B.; Martinez-Gomariz, E. Assessment of Inlet Efficiency through a 3D Simulation: Numerical and Experimental Comparison. Water Sci. Technol. 2016, 74, 1926-1935. [CrossRef]

51. Tang, Y.; Zhu, D.; Rajaratnam, N.; Duin, B.V. Experimental Study of Hydraulics and Sediment Capture Efficiency in Catchbasins. Water Sci. Technolo. 2016, 74, 2717-2726. [CrossRef]

52. Veerappan, R.; Le, J. Hydraulic Efficiency of Road Drainage Inlets for Storm Drainage System under Clogging Effect. In Proceedings of the Proc. 5th International Conference on Flood Risk Management and Response, San Servolo, Italy, 29 June-1 July 2016; pp. 271-281.

53. Schalla, F.E.; Ashraf, M.; Barrett, M.E.; Hodges, B.R. Limitations of Traditional Capacity Equations for Long Curb Inlets. Transp. Res. Rec. J. Transp. Res. Board 2017, 2638, 97-103. [CrossRef]

54. Rubinato, M.; Lee, S.; Martins, R.; Shucksmith, J.D. Surface to Sewer Flow Exchange through Circular Inlets during Urban Flood Conditions. J. Hydroinformatics 2018, 20, 564-576. [CrossRef]

55. Virahsawmy, H.K.; Stewardson, M.J.; Vietz, G.; Fletcher, T.D. Factors that Affect the Hydraulic Performance of Raingardens: Implications for Design and Maintenance. Water Sci. Technolo. 2014, 69, 982-988. [CrossRef]

56. Li, X.; Fang, X.; Gong, Y.; Li, J.; Wang, J.; Chen, G.; Li, M.-H. Evaluating the Road-Bioretention Strip System from a Hydraulic Perspective-Case Studies. Water 2018, 10, 1788. [CrossRef]

57. SWMM. Available online: https://www.epa.gov/water-research/storm-water-management-model-swmm (accessed on 2 March 2020).

58. PCSWMM. Available online: https://www.pcswmm.com/ (accessed on 10 April 2020).

59. Duchene, M.; McBean, E.A. Discharge Characteristics of Perforated Pipe for Use in Infiltration Trenchces. Water Res. Bull. AWWA 1992, 28, 517-524. [CrossRef]

60. Afrin, T.; Khan, A.A.; Kaye, N.B.; Testik, F.Y. Numerical Model for the Hydraulic Performance of Perforated Pipe Underdrains Surrounded by Loose Aggregate. J. Hyraulic. Eng. ASCE 2016, 142, 1-10. [CrossRef]

61. Liu, H.; Zong, Q.; Lv, H.; Jin, J. Analytical Equation for Outflow along the Flow in a Perforated Fluid Distribution Pipe. PLoS ONE 2017, 12, 1-18. [CrossRef]

62. Qin, Z.; Liu, H.; Wang, Y. Empirical and Quantitative Study of the Velocity Distribution Index of the Perforated Pipe Outflowing Along a Pipeline. Flow Meas. Instrum. 2017, 58, 46-51. [CrossRef]

63. Paul, U.; Karpf, C.; Schalk, T. Hydraulic Simulation of Perforated Pipe Systems Feeding Vertical Flow Constructed Wetlands. Water Sci. Technolo. 2018, 77, 1431-1440. [CrossRef]

64. FLOW-3D. Available online: https://www.flow3d.com/ (accessed on 2 March 2020).

65. City of Toronto InfoWorks CS Basement Flooding Model Studies Guideline. Available online: https://wx.toronto.ca/inter/pmmd/callawards.nsf/0/85258049005DEA63852580BB005C66C0/\$file/911717-7015\%20Addendum\%203\%20Attachment\%20-\%20Modelling\%20Guidelines_October\%202014.pdf (accessed on 13 April 2020).

66. Abida, H.; Sabourin, J.F.; Ellouze, M. ANSWAPPS: Model for the Analysis of Grass Swale-Perforated Pipe Systems. J. Irrig. Drain. Eng. ASCE 2007, 133, 211-221. [CrossRef]

(C) 2020 by the authors. Licensee MDPI, Basel, Switzerland. This article is an open access article distributed under the terms and conditions of the Creative Commons Attribution (CC BY) license (http://creativecommons.org/licenses/by/4.0/). 